See discussions, stats, and author profiles for this publication at: https://www.researchgate.net/publication/228643444

\title{
Geophysical, geochemical and geodetical signals of reawakening at Turrialba volcano (Costa Rica) after almost 150 years of quiescence
}

Article in Journal of Volcanology and Geothermal Research · November 2010 Dol: 10.1016/j.jvolgeores.2010.09.021

\section{CITATIONS}

53

7 authors, including:

\section{Francesca Martini}

Tullow Oil plc

39 PUBLICATIONS 282 CITATIONS

SEE PROFILE

Orlando Vaselli

University of Florence

572 PUBLICATIONS 6,516 CITATIONS

SEE PROFILE
READS

225

Franco Tassi

University of Florence

517 PUBLICATIONS 4,425 CITATIONS

SEE PROFILE

Rodrigo del Potro

40 PUBLICATIONS 389 CITATIONS

SEE PROFILE

Some of the authors of this publication are also working on these related projects:

Volcanic Lakes of El Salvador View project

Reconocimiento del sistema kárstico de Venado de San Carlos y sus implicaciones espeleológicas, hidrogeológicas, geológicas y geo-turísticas View project 
Provided for non-commercial research and education use. Not for reproduction, distribution or commercial use.

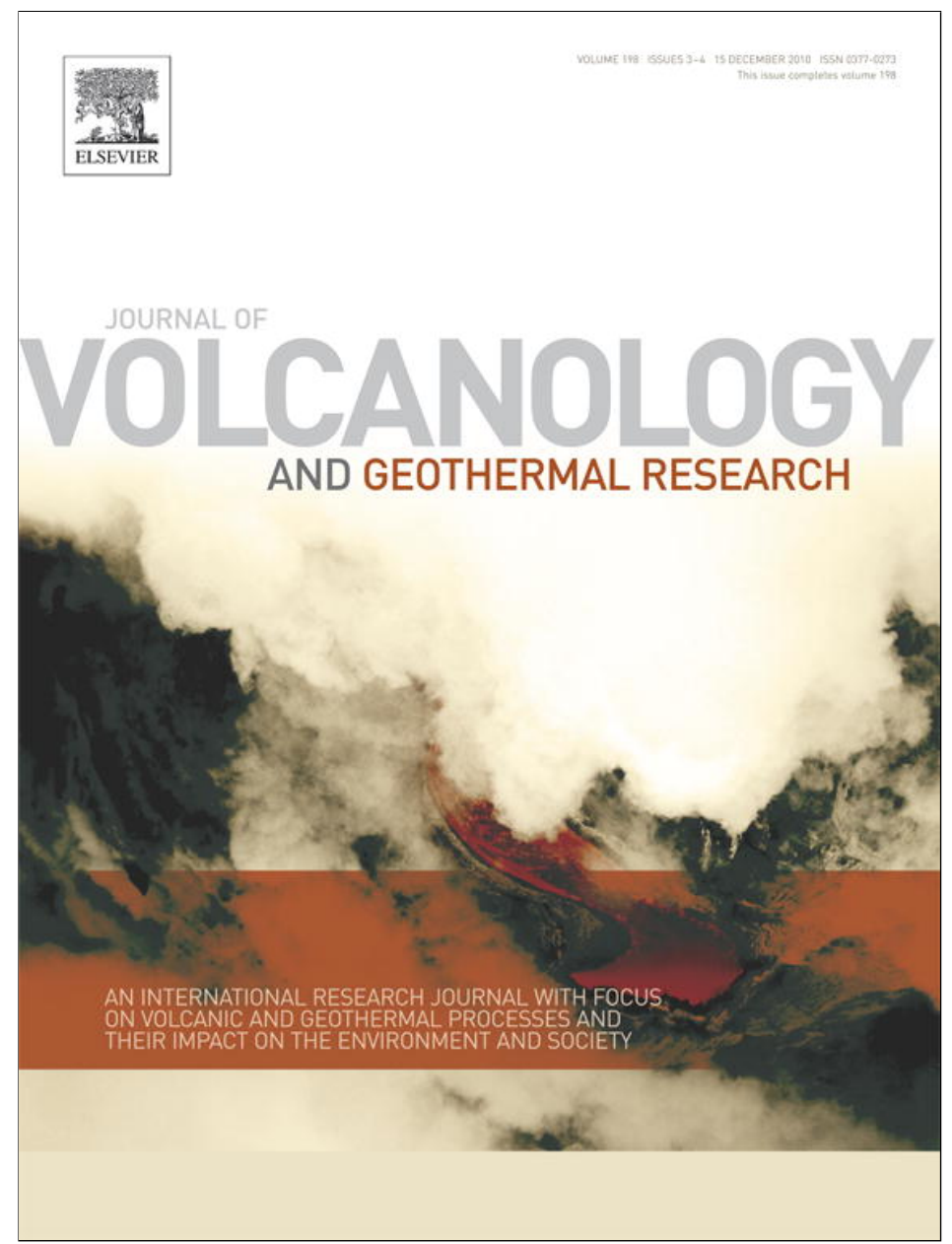

This article appeared in a journal published by Elsevier. The attached copy is furnished to the author for internal non-commercial research and education use, including for instruction at the authors institution and sharing with colleagues.

Other uses, including reproduction and distribution, or selling or licensing copies, or posting to personal, institutional or third party websites are prohibited.

In most cases authors are permitted to post their version of the article (e.g. in Word or Tex form) to their personal website or institutional repository. Authors requiring further information regarding Elsevier's archiving and manuscript policies are encouraged to visit:

http://www.elsevier.com/copyright 


\title{
Geophysical, geochemical and geodetical signals of reawakening at Turrialba volcano (Costa Rica) after almost 150 years of quiescence
}

\author{
F. Martini ${ }^{\mathrm{a}, \mathrm{b}, *}$, F. Tassi ${ }^{\text {c,d }}$, O. Vaselli ${ }^{\text {c,d }}$, R. Del Potro ${ }^{\mathrm{b}, 1}$, M. Martinez $^{\mathrm{b}}$, R. Van del Laat ${ }^{\mathrm{b}}$, E. Fernandez $^{\mathrm{b}}$ \\ a Seismology and Computational Rock Physics Lab., School of Geological Sciences, University College Dublin, Belfield, Dublin 4, Ireland \\ b Observatorio Volcanológico y Sismológico de Costa Rica OVSICORI-UNA, Universidad Nacional, Apdo 2346-3000, Heredia, Costa Rica \\ ${ }^{c}$ Department of Earth Sciences, University of Florence, Via La Pira 4, 50121 Florence, Italy \\ d CNR-IGG Institute of Geosciences and Earth Resources, Via La Pira 4, 50121 Florence, Italy
}

\section{A R T I C L E I N F O}

\section{Article history:}

Received 9 February 2010

Accepted 29 September 2010

Available online 17 October 2010

\section{Keywords:}

volcano unrest

Turrialba volcano

volcano seismicity

magmatic degassing

Costa Rica

\begin{abstract}
A B S T R A C T
Turrialba is a basaltic-andesitic stratovolcano (3340 masl), in the Cordillera Volcánica Central in Costa Rica. After the last eruption (1864-1866), volcanic manifestations were limited to weak fumarolic discharge (continuous since 1980) from the summit. From 1996 onward, the degassing activity has progressively been increasing, reaching its climax after 2005. New fumaroles have appeared in the Central and West summit craters, the latter now being the most active, and in the fracture system in between, showing sulphur deposits and progressively increasing degassing rate. In 2004, fumaroles and new fissures have appeared on the SW outer and SSW distal flanks, the latter being located along a major NE-oriented tectonic lineament. Fumarolic temperatures at the bottom of the West crater have increased from 88 to $282{ }^{\circ} \mathrm{C}$ in early 2008 . Changes in chemical and isotopic compositions of discharged fluids have shown a progressive enhancing of the magmatic signature since 2001. Since late 2007, $\mathrm{SO}_{2}$ flux, measured with mini-DOAS, has increased two orders of magnitude ( $1 \mathrm{t}$ /day in 2002 to $740 \mathrm{t} /$ day in January 2008). The enhanced gas discharge at Turrialba volcano has caused significant interference on tropospheric $\mathrm{O}_{3}$ measurements at $2-3 \mathrm{~km}$ altitude $\sim 50 \mathrm{~km}$ Wrom the volcano. Seismic swarms followed an increasing trend consistent with that of the fumaroles. The maximum seismic activity to date, up to thousands of events/day, was recorded in mid 2007. An inflationary trend was observed in the crater area.

In this paper we present for the first time all the available data on the activity of Turrialba volcano. New geophysical, geodetical and geochemical data and published geophysical and geochemical data are presented and discussed as a whole. The multidisciplinary approach indicated that from 1996 to 2009 three stages, deriving by the delicate equilibrium between the hydrothermal and the magmatic reservoirs, were recognized. The magmatic-dominated phase is still prevailing as evidenced by the fact that, while completing the present paper, on the 4th of January 2010 at 16.57 (GMT) a loud explosion occurred at the West crater and was followed by three others spaced out every $10 \mathrm{~min}$. These events were interpreted as associated with phreatic eruptions.
\end{abstract}

(c) 2010 Elsevier B.V. All rights reserved.

\section{Introduction}

The Turrialba basaltic-andesitic stratovolcano (3340 masl) is the south-easternmost active volcano of the Cordillera Volcánica Central (CVC) in Costa Rica, located at about $10 \mathrm{~km}$ NE from the CVC main axis. The CVC is aligned in a N60 W direction, at about $150 \mathrm{~km}$ from

* Corresponding author. Seismology and Computational Rock Physics Lab., School of Geological Sciences, University College Dublin, Belfield, Dublin 4, Ireland. Tel.: + 3531 716 2137; fax: + 35312837733 .

E-mail addresses: francesca.martini@ucd.ie (F. Martini), franco.tassi@geo.unifi.it (F. Tassi), orlando.vaselli@unifi.it (O. Vaselli),r.delpotro@bristol.ac.uk (R. Del Potro), mmartine@una.ac.cr (M. Martinez), rvanderl@una.ac.cr (R.V. del Laat).

${ }^{1}$ Now at: Department of Earth Sciences, University of Bristol, Wills Memorial Building, Queens Road, Bristol BS8 1RJ, United Kingdom. the subduction trench of the Cocos Plate underneath the Caribbean Plate (Protti et al., 1995, 2001) (Fig. 1).

Turrialba volcano has a volume of approximately $290 \mathrm{~km}^{3}$ while the entire edifice has a radius of about $20 \mathrm{~km}$, extending from the town of Turrialba to the Guápiles plane and from the basin of Río Toro Amarillo to the vicinity of the Río Reventazón basin (Soto, 1988) (Fig. 2). Turrialba and the nearby Irazú volcano, with which it shares the base (twin volcanoes), form the largest volcanic massif of Central America (Carr et al., 1990).

The currently active edifice is conical with an elliptical summit area (facing to the NE) that hosts at least three craters, labelled East, Central and West, according to their geographical position, as well as three exterior peaks, Cerro San Carlos to the N, Cerro San Enrique to the E and Cerro San Juan to the S-W (Fig. 2). The age of the three craters decreases from $\mathrm{E}$ to $\mathrm{W}$ (the latter formed during the last 


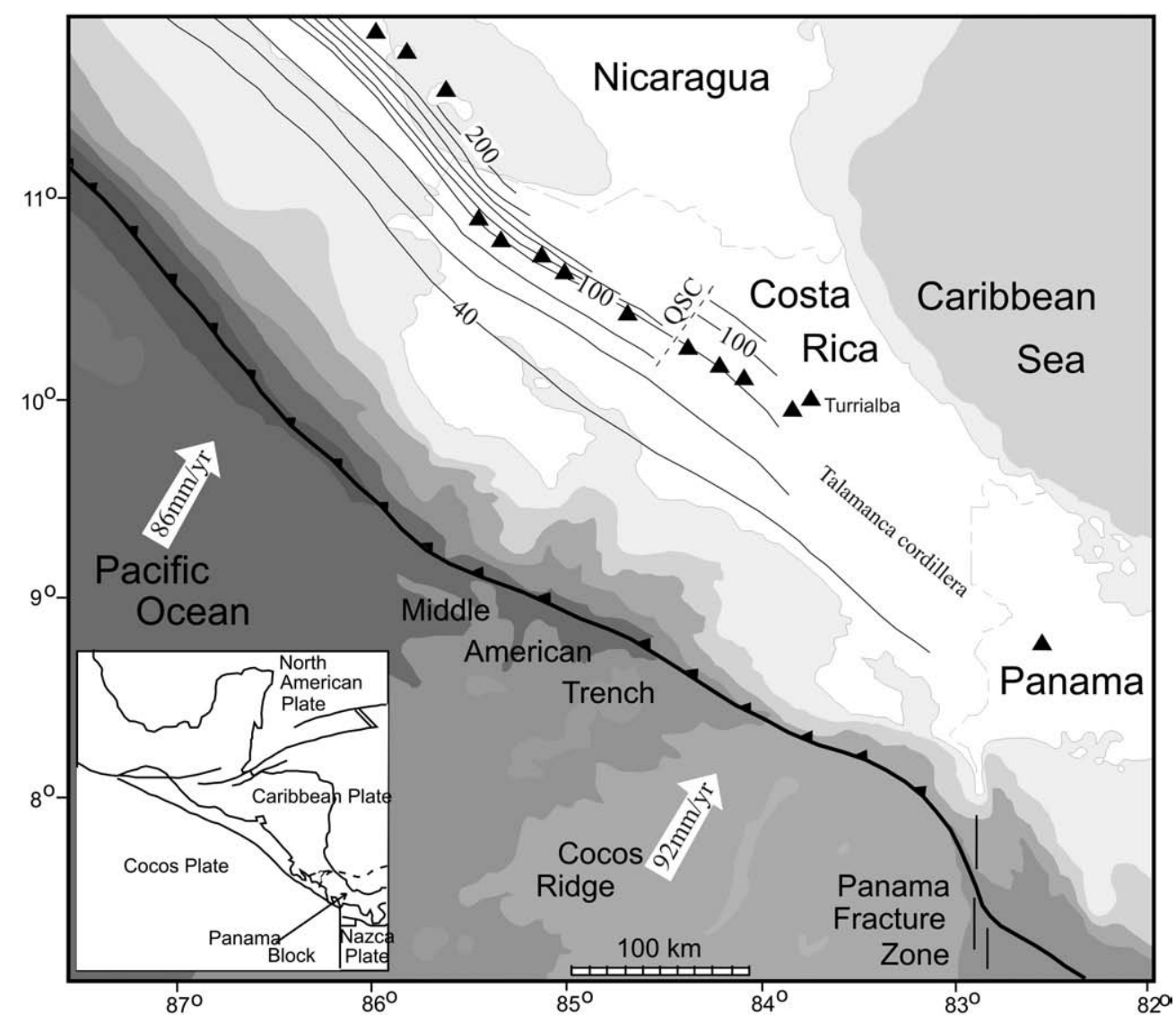

Fig. 1. Tectonic setting of Costa Rica (modified from Protti et al., 1995). Black triangles mark the volcanoes of the Cordillera Volcanica Central.

eruptive event in 1864-66). Other craters are present but not clearly recognizable, being disfigured by volcanic and erosive effects (Alvarado-Induni, 2005).

The edifice's morphology is characterized by its prominent northeast facing valley, attributed to either a sector collapse (Soto, 1988) or glacial erosion (Soto, 1988; Reagan et al., 2006). Normal faults cut through the summit region (Linkimer-Abarca, 2003) and follow for several kilometres a NE-SW direction along which two pyroclastic cones, named Tiendilla and El Armado, are aligned (Soto, 1988) (CT and CA in Fig. 2).

From its last eruption to the early 1990s, Turrialba has been characterized by the emission of discontinuous low temperature $\left(<95^{\circ} \mathrm{C}\right)$ fumarolic gases discharging from the Central and West craters, with occasional reports of a small plume visible in the areas surrounding the volcano (http://www.ovsicori.una.ac.cr/ vulcanologia/estado_volcanes.htm). The fumarolic gas discharges have been continuous since 1980 (Cheminée et al., 1982; Tassi et al., 2004). From 1996 onwards, Turrialba has been showing worrying reawakening signals in terms of both seismicity and gas geochemistry. The increasing number of seismic events has been paralleled by enhanced fumarolic activity (accompanied by higher outlet temperatures and significant compositional variations) and, opening of new fumarolic vents in both Central and West craters as well as in the outer and external flanks of the volcano (http://www. ovsicori.una.ac.cr/vulcanologia/estado_volcanes.htm).

These physical-chemical changes at Turrialba, after almost 150 years of relative quiescence, have led to a closer surveillance. Turrialba is upwind from the highly populated Central Valley, which includes the capital city San José and most of Costa Rica's other large population centres, as well as its main international airport. Therefore, Turrialba could pose a severe hazard to both the population and the economy of Costa Rica.
In this paper new geophysical, geodetical and geochemical $\left(\mathrm{SO}_{2}\right.$ flux, Radon and rainwater) data are presented and discussed with previously published geochemical (geochemistry of fumarolic discharges; Tassi et al., 2004; Vaselli et al., 2010) and geophysical ${ }^{2}$ (Barboza et al., 2003a,b) data gathered from monitoring activity. A particular emphasis is devoted to the 2007-2008 period, when Turrialba suffered the most dramatic changes. While new efforts, resources and equipments have been dedicated to the monitoring and understanding of this volcano since early 2009 , the main goal of this work is to show and interpret the multidisciplinary dataset to assess the status of the volcano's activity and provide reliable scenarios of its possible evolution. The intention is to highlight i) a multiparametric approach useful in understanding the activity of a volcano (even when the resources are limited as they were up to recently for Turrialba volcano) and ii) present for the first time all the available data on the activity of this specific volcano- some already published (Tassi and Vaselli's work) and a whole suite of data in most cases never used before, or only shown in local reports. For the first time all these data are presented together and discussed as a whole, in a multiparametric approach.

\section{Eruptive history and volcanic hazard}

Outcrops of basaltic to dacitic lava and pyroclastic units from at least twenty eruptions are recorded in the summit area (Soto, 1988), some of which are associated with major lava flows along Turrialba's northern, western and southern flanks. The majority of these eruptions likely preceded an important erosional period that may

\footnotetext{
${ }^{2}$ The only published geophysical data are relative to seismicity levels/event counts (no analysis) up to 2002 (Barboza et al., 2003a,b). More recent information on seismicity levels was only presented in the OVSICORI-UNA internal reports.
} 


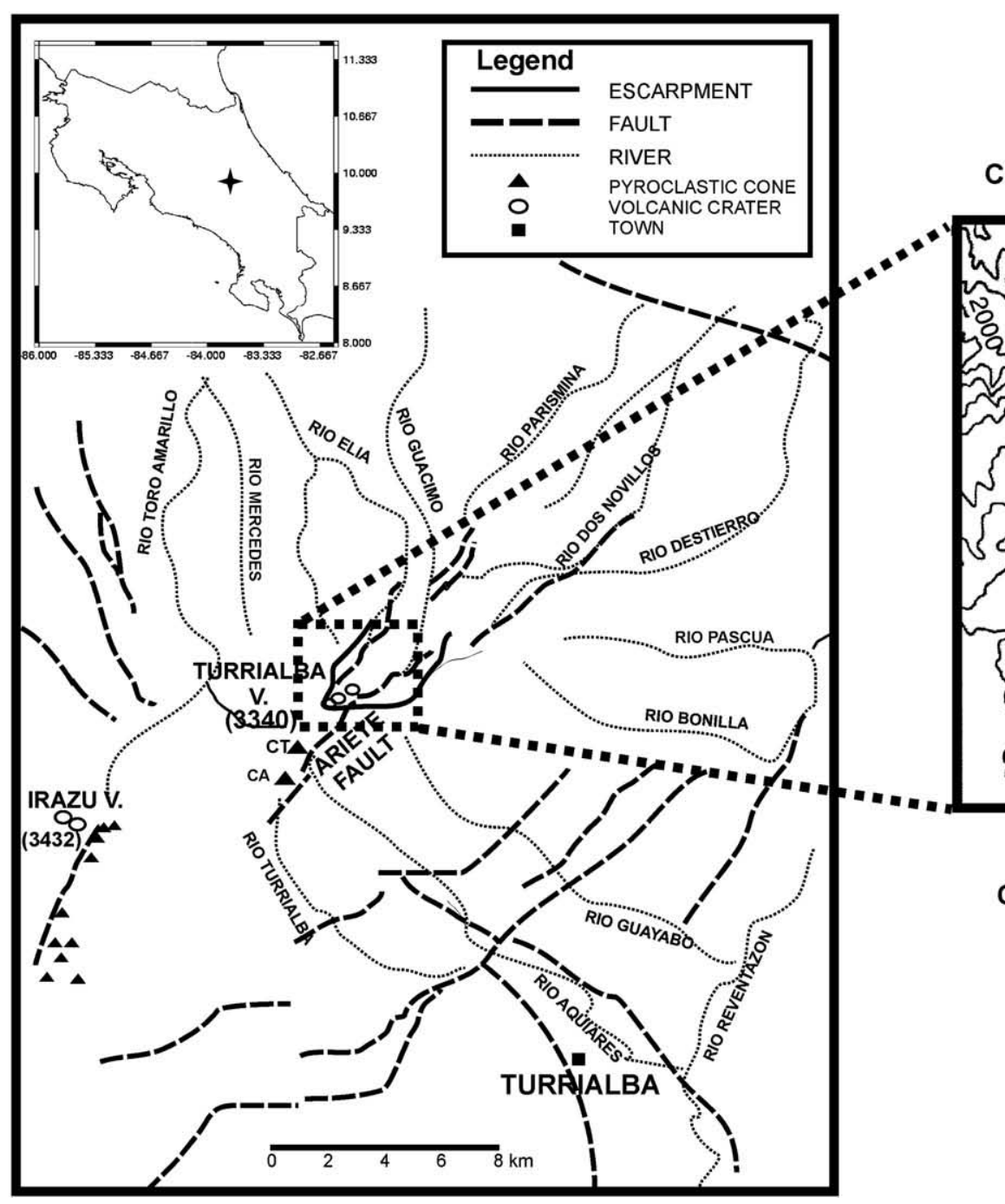

Fig. 2. Location, main morphology and tectonic features of Turrialba area (freely redrawn from Soto (1988), Linkimer-Abarca (2003) and Reagan et al. (2006)). The right-hand-side inset is a topographic map of Turrialba summit region, with contours at $100 \mathrm{~m}$ intervals; the rim of the NE valley is outlined with dashed lines. The three craters of Turrialba summit are marked W (West crater), C (Central crater) and E (East Crater). CT = Pyroclastic cone Tendilla, CA = Pyroclastic cone El Armado.

have involved glaciation, also marked by dearth of volcanism (Reagan et al., 2006). The post-erosional period began with massive andesite to dacite lava flows at ca. 9300 year B.P.

Six explosive eruptions are recorded in the tephra stratigraphy at Turrialba over the last 3400 years (Soto, 1988; Alvarado-Induni, 2005). Setting aside a $0.2 \mathrm{~km}^{3}$ silicic andesite Plinian eruption at ca. 1970 yrs B.P., these eruptions were small volume $\left(<0.03 \mathrm{~km}^{3}\right)$ basalt and basaltic andesite phreatic and phreatomagmatic eruptions (Reagan et al., 2006).

The last eruption occurred in 1864-1866, following a period of enhanced fumarolic activity that started in 1723 (Reagan et al., 2006). It was an entirely explosive eruption: phreatic in the first year, phreatomagmatic towards the end and characterized by the emission of relatively large volumes of ashes that during the peak of activity (February 1866) reached Nicaragua (Reagan et al., 2006).

Over the last 3400 years, repose periods have averagely lasted 800-600 years, although the interval between the 1864-66 and the previous eruption was likely much shorter as suggested by the thin soil horizon that separates these two events (Reagan et al., 2006).

The geological and rock geochemistry records suggest that the next eruption, likely occurring from the summit craters, is expected to be similar to the most recent basaltic and basaltic andesitic eruptions, although a larger volume and/or a more destructive silicic andesite to dacite eruption cannot be ruled out (Reagan et al., 2006). The presence of young cinder cones on the SW flank of Turrialba does not allow discarding the possibility of eruptive events away from the craters. Depending on whether the eruption would stop at an initial phreatic phase or would be followed by a strombolian or phreatomagmatic phase, fallout deposits could severely affect the entire Central Valley (Reagan et al., 2006). In addition, Turrialba is characterized by: steep slopes, massive lavas overlying weak pyroclastic substratum, widespread hydrothermal alteration of the core of the volcano, vent migration parallel to the axis of the avalanche caldera and water saturation of the edifice. All these features may promote a failure of the volcano edifice, enhancing the risk of debris avalanching (Reagan et al., 2006).

\section{Monitoring techniques}

Seismic surveillance of Turrialba volcano started in 1990 with a single station located at the summit of the volcano equipped with a $1 \mathrm{~Hz}$ Ranger SS1 seismometer, managed by the Observatorio Vulcanológico y Sismológico de Costa Rica Universidad Nacional, OVSICORI-UNA. In 1996, three short-period telemetric stations (donated to OVSICORI-UNA by the USGS Volcano Disaster Assistance Programme-VDAP) were added. Hence, the current network is consisting of 3 L4C Mark 1-component and 13 -component seismometers (L4D sensors for the horizontal components, a Ranger SS1 
seismometer for the vertical one). Station locations are shown on the map in Fig. 3a. Previously recorded in trigger mode, since April 2008 the seismic signals are recorded in continuous mode.

In the 1980s OVSICORI-UNA began the installation and measurements of geodetic networks on active Costa Rican volcanoes, including Turrialba. Four dry tiltmeters (triangular levelling arrays) were set at Turrialba in 1982 and measurements were initially carried out quarterly and twice a year since 1987 (due to the low level of activity of Turrialba) until 2000, when measurements were interrupted. After 1990, EDM (electronic distance measurement) and trigonometric levelling networks improved the existing tiltmeters. The current geodetic network (Fig. 3b), equipped with a Trimble 5601 precise Total Station, includes two independent EDM networks, located at both the SW flank and the crater summit of the volcano. The two EDM networks, where distances and zenith angles are measured between one reference point and several fixed prisms, were installed in 2002 and 2006, respectively. These data have not been previously published.

The entire geodetic network is located within or very near the summit region and thus well inside the area of expected ground deformation in case of intrusion (this poses some limitations in absolutely quantifying the deformation). Moreover, the lack of fix reference benchmarks resulted in that only two-dimensional differential displacement between two possibly moving points could have been detected. Therefore, while the networks are being improved at the time of writing, the data collected up to 2008 can only infer on the occurrence of deformation but make impossible to properly characterize or quantify it.

OVSICORI-UNA and the University of California at Santa Cruz have been operating, since 2002, an Applied Geomechanics Inc. ${ }^{\text {TM }}$ Model 800 uniaxial electronic tiltmeter on the SW flank of Turrialba volcano. This electronic tiltmeter is radially oriented and located about $1.7 \mathrm{~km}$ from the crater (location indicated by white star in Fig. 3b). The instrument is bolted down on a concrete pier about a meter deep, protected and insulated by a plastic barrel buried some $50 \mathrm{~cm}$ below the surface. The analogue output of this tiltmeter is digitally converted and recorded by a Campbell Scientific Inc. ${ }^{\text {TM }}$ Model CR500 data-logger located on a metal box a meter above ground. Although daily and seasonal temperature ranges of the data-logger are 15 and $30^{\circ} \mathrm{C}$, respectively, temperatures at the pier, where the tiltmeter is located, are varying between 1 and $3.5^{\circ} \mathrm{C}$ on a daily and yearly basis, respectively. Sampling rate was every 5 min from 2002 to mid 2003 and twice per hour since mid-2003. These data have not been previously published.

Four GPS campaigns have been carried out since 2006 in the volcano summit area (benchmarks are shown in Fig. 3b). The reference point was an external CGPS (Continuous GPS) station located in San José, $40 \mathrm{~km}$ away from the network (CRCC-CORS station managed by COGNOCARTA/CENAT). In the last campaign (2008) a fixed benchmark, located near the summit of the neighbouring Irazú volcano, $10 \mathrm{~km}$ away from the Turrialba network and at the same elevation, was also used. This was done due to previous large uncertainties in vertical measurements attributed to the elevation difference between the network and the reference station in San José $(\sim 2000 \mathrm{~m})$. These data have not been previously published.

The monitoring of the fumarolic gas discharges has started in 1980 by measuring outlet temperatures, condensates $(\mathrm{pH}, \mathrm{F}$ and $\mathrm{Cl})$, rainwaters ( $\mathrm{pH}$, electrical conductivity and main solutes), $\mathrm{SO}_{2}$ fluxes and Radon measurements by the OVSICORI-UNA personnel (previously unpublished data). In the last fifteen years, in collaboration with the Department of Earth Sciences of Florence (Italy), the geochemical monitoring was implemented by including chemical (inorganic and organic) and isotopic (oxygen and hydrogen in steam, carbon in $\mathrm{CO}_{2}$ and helium) analysis of fumarolic gases.

Outlet temperatures and condensates from the fumarolic discharges located within the Central and West summit craters (Fig. 3c) were measured at variable time intervals, depending on the status of the volcanic activity and weather conditions. Complete geochemical analysis and, more sporadically, isotopic data for the Central and West crates are available, once or twice per year, since 1998 (Tassi et al., 2004; Vaselli et al., 2010). The Quemada fumarolic field, which formed in summer 2001 in a large fractured area between the West and Central crater, was sampled in 2002. Gas discharges from the SW flanks of the volcano were collected in 2008, while those seeping out in correspondence of the Ariete Fault, a major tectonic fault $1.7 \mathrm{~km}$ SW of the summit craters, were sampled for the first time in 2007.

Rainwater samples were collected on a monthly basis from a network of rain gauges in the surroundings of the summit area (Fig. 3c) at: i) the rim of the West crater since 2003, and ii) La Silvia Station located on the western flank of the volcano in 1984-1986 (Fernández, 1987) and from 2007 onwards. Samples were stored in high-density clear polyethylene bottles and kept at $5{ }^{\circ} \mathrm{C}$ to minimize the growth of bacteria or algae (Martínez, 2008; unpublished). Additional (unpublished) rainwater samples are collected by the Costa Rican Institute of Electricity (Instituto Costarricense de Electricidad, ICE) on a monthly basis since April 2007 at seventeen sites, mainly located on the W, SW and S flanks on the volcano edifice (Soto et al., 2008).

Mini-DOAS profiles, to estimate the $\mathrm{SO}_{2}$ flux rates at Turrialba volcano, were measured at irregular intervals from 2002 to 2007 by traversing the volcanic plume on foot with a portable miniaturized Ocean Optics USB2000 UV spectrograph fibre-coupled to a pointing telescope, which has an optical resolution of ca. $0.6 \mathrm{~nm}$ over a wavelength range of $245-380 \mathrm{~nm}$ (the Scanning Dual-beam miniature - Differential Optical Absorption Spectrometer, so called miniDOAS) (Platt, 1994). The instrument was operated in zenith sky mode with a custom-built programme, mobile DOAS, developed specially for DOAS measurements (Galle, 2002; Galle et al., 2003). In April 2008, a network of four fixed mini-DOAS stations was set up on the western flank of Turrialba volcano (Fig. 3c) within the NOVAC project (http:// www.novac-project.eu), to continuously monitor the $\mathrm{SO}_{2}$ flux through the summit craters of Turrialba volcano (unpublished data).

Radon has been monitored on the volcano (Fig. 3c) since 1983 by OVSICORI-UNA and the Centre National de la Recherche Scientifique (CNRS) in France. Radon flux was determined following the technique of Seidel (1982) based on Solid State Nuclear Track Detectors (SSNTD). The SSNTD used are alpha-sensitive LR-115 type II cellulose nitrate foils, manufactured by KODAK-PATHE. The foils were left in the field during mean exposure periods of 30 days and systematically substituted in order to maintain a continuous surveillance (unpublished data).

\section{The recent evolution of Turrialba volcano: chronology and observations}

After many years of quiescence, the activity at Turrialba resumed in 1996 with a marked and progressive increase in degassing and seismic activity. The increased seismicity was characterized by the occurrence of periodic seismic swarms, the most important ones in 2001, 2003, 2004, 2005 and 2007, when the highest peaks of seismicity were recorded. An increment in the number of fumaroles and levels of degassing has been observed at the occurrence of each seismic swarm (Barboza et al., 2003b; Tassi et al., 2004; Vaselli et al., 2010).

Before 2000, the fumarolic activity from the summit area was mainly from two low-flux fumaroles located in the Central and West craters (Tassi et al., 2004). In 2000, new fumaroles appeared in the two craters and in the fracture system in between.

Coeval to swarms in 2001 and 2002, a change in the fumarolic gas composition was observed, while radial inflation was detected. In summer 2001, a large fracture (30 $\mathrm{m}$ long and $4 \mathrm{~m}$ wide) between the West and the Central crater started discharging fluids at $90{ }^{\circ} \mathrm{C}$ (Quemada fumarolic field) in parallel to a significant increase of the 

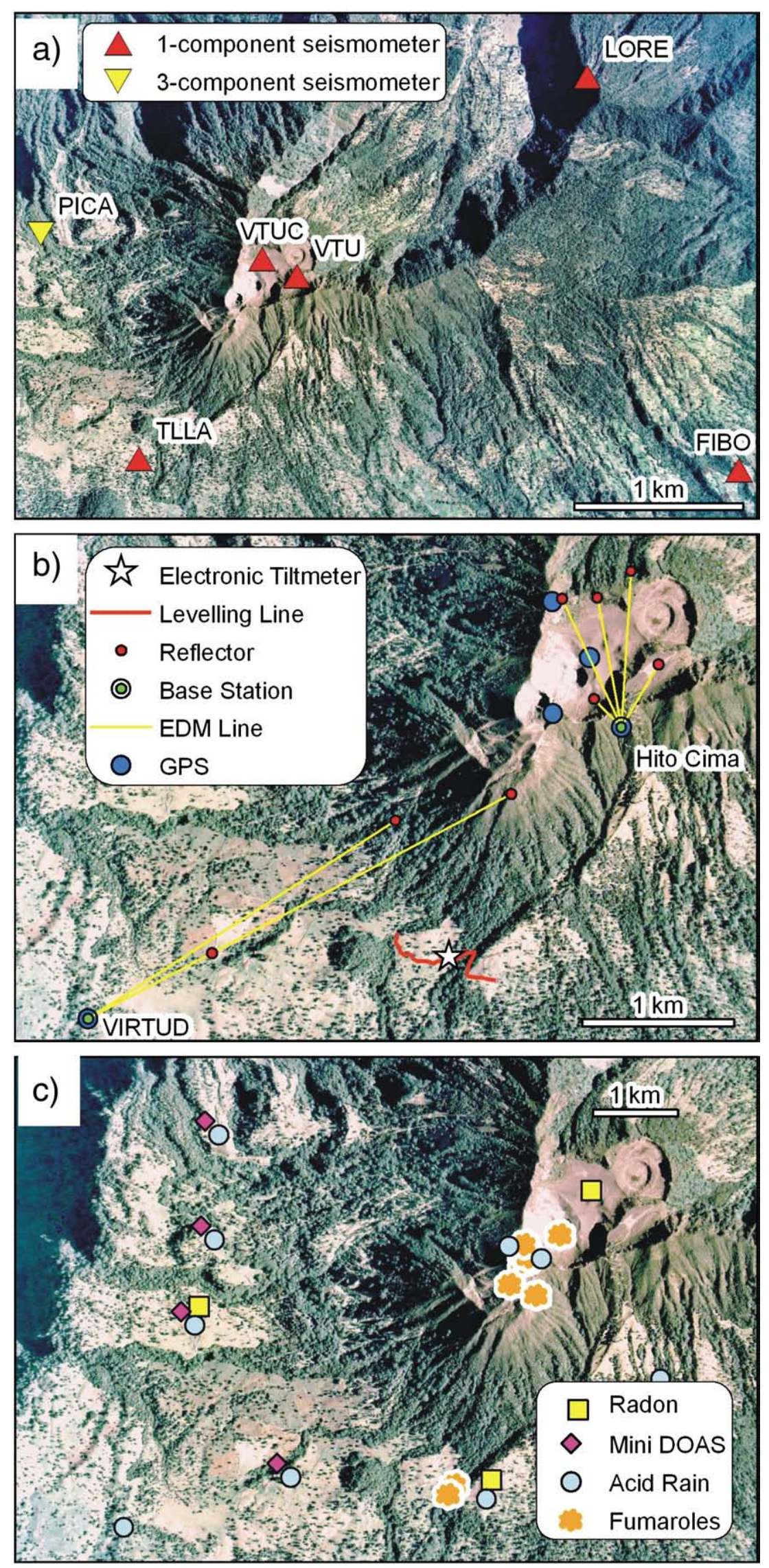

Fig. 3. Location of the monitoring stations and sampling points; a) seismic stations (current crater station VTU, which substituted VTUC in 2007), b) geodetic network, EDM reflector and GPS points, and tiltmeter location, and c) fumaroles, mini-DOAS stations, rain gauges, radon sampling points. 
degassing rate from the fumaroles of the Central crater (Barboza et al., 2003a; Tassi et al., 2004).

Gas emission flux and temperature increased again in 2004 in correspondence to several swarms of hybrid events. In 2005, a general increase of the fumarolic activity and the opening of new fumarolic vents were observed, in the West crater area (mainly in the northern and eastern flanks) as well as SW of the crater area at a much lower elevation (2600 masl).

Following the high seismicity recorded in 2007, degassing from the West crater considerably increased and a new jet high-flux fumarole appeared at its bottom (hereafter West HT fumarole). Coincidentally, the most evident changes (temperature, degassing levels, etc.) have been observed at the volcano. Since then a plume, occasionally up to $2 \mathrm{~km}$ high above the crater level, has almost constantly been observed (http://www.ovsicori.una.ac.cr/vulcanologia/estado_volcanes.htm). Sulphur deposits have appeared at the fumaroles, particularly at the bottom of the West crater. New fumaroles also appeared at the Ariete fault, in February 2007.

In the following sections, a detailed description is given on the seismicity, ground deformation, gas geochemistry, $\mathrm{SO}_{2}$ flux, radon measurements, rainwater chemistry and the impact on the environment by the fumarolic-induced volcanic plume at Turrialba volcano over the recent years.

\section{The recent evolution of Turrialba volcano: geophysical and geochemical evidences}

\subsection{Seismicity ${ }^{3}$}

Smithsonian (Global Volcanism Program) Bulletins for Turrialba volcano (http://www.volcano.si.edu/world/volcano.cfm?vnum= 1405-07=\&volpage=var) and Barboza et al. (2003a) reported relatively low seismicity (a maximum of 90 hybrid event/month) in the years 1990-1996; periodic seismic swarms started in 1996. From May 1996, the micro-seismicity (characterized by frequencies between 2.4 and $4 \mathrm{~Hz}$, short duration, amplitude $<10-15 \mathrm{~mm}, \mathrm{~S}-\mathrm{P}$ smaller than $1 \mathrm{~s}$ and $\left.\mathrm{M}_{\mathrm{d}}<1\right)$ increased. Small amplitude, low frequency $(<2 \mathrm{~Hz})$ events of $\mathrm{M}_{\mathrm{d}}<1.6$ were recorded and reached 600 events/month toward the end of the year. In February 1997 a small increase in the microseismicity, both in number of events (reaching up to 2000/month) and magnitude, was detected. A further increase was recorded in July 1998, coeval with the appearance of new fumaroles. The year 2000 was marked by the appearance of seismic swarms of hybrid events, which characterized the following years. The first swarm occurred between October 19th and November 4th; it consisted of hybrid events with $M_{d}<1.9$, localized within the volcano edifice at a depth between 4 and $6 \mathrm{~km}$.

In January, March and October 2001 and October 2002, four seismic swarms of hybrid events with frequency between 2.1 and $3.5 \mathrm{~Hz}$ affected the Turrialba volcanic system. LP events with dominant frequency $<1.8 \mathrm{~Hz}$ and $\mathrm{M}_{\mathrm{d}}$ up to $\approx 2.0$ were also recorded. Hypocentral determination localized these events within the volcano edifice at a depth of 4-6 km, mainly along the northern flank, within a $4 \mathrm{~km}$ distance from the crater area (http://www.ovsicori.una.ac.cr/ vulcanologia/estado_volcanes.htm). Another swarm occurred in JulyAugust 2003: the appearance of low frequency $(<2 \mathrm{~Hz})$ tremor at all stations followed this episode.

Volcanic tremor and the appearance of a small number of tornillotype events characterized 2005. A swarm of hybrid events was recorded in April 2006, consisting of intermittent tremor with 3.2, 3.8 and $4.3 \mathrm{~Hz}$ central frequency and VT events marked the opening of

\footnotetext{
${ }^{3}$ All the data relative to the seismicity levels have been extracted from the OVSICORI-UNA internal reports, unless otherwise indicated. The data analysis is original to this manuscript.
}

new fractures within the crater area as well as the northern flank of the volcano during the same year.

Between June 2005 and February 2007 the permanent network recorded small seismic swarms of events with $M=1.2-1.9$, at a depth between 4 and $6 \mathrm{~km}$ in several occasions. All those events were classified as hybrid on the basis of their waveform and frequency content.

In April-May and July-September 2007 two seismic swarms were recorded. In July 2007 the maximum activity to date, with 2000 event/ day, for several days, was recorded.

The events are interpreted as VT type (some examples from the April/May swarm are shown in Fig. 4). At the crater station (VTU), these events were recorded with an impulsive start and frequencies up to $8 \mathrm{~Hz}$; at the other stations (PICA, LORE, TLLA and FIBO), positioned at variable distance from the crater area (Fig. 3a), their onset became progressively more emergent, they lost the higher frequency content (frequency reaching $4 \mathrm{~Hz}$ only at a distance of $\sim 2.5 \mathrm{~km}$ from the crater area), and showed smaller amplitudes and longer coda. All these effects can be explained as due to propagation effects in the highly scattering volcanic structure.

A second swarm, the biggest to date, occurred from late July to mid September 2007; the peak of activity, recorded on July 19th, reached 2000 events/day. The events are interpreted as VT type, the number of episodes being much higher than that recorded in the previous swarm.

The peak in seismic activity in mid 2007 marked an important change in the seismicity character. The predominant seismicity was then characterized by strongly emergent events, with a typical spindle-shape envelope waveform and frequencies up to $12 \mathrm{~Hz}$, although most were between 2 and $8 \mathrm{~Hz}$. Polarization analysis of the events recorded by the only available 3 component station (PICA, $2.1 \mathrm{~km} \mathrm{~W}$ of the crater) performed following the method of Kanasevich (1981) revealed azimuth angles of approximately $80 \mathrm{~N}$ (pointing into the general direction of the crater area) and dip angles approaching 80 to $90^{\circ}$, indicating very shallow events. The events showed a striking similarity to the seismograms recorded for the active seismic experiment at Merapi volcano (Wegler and Luhr, 2001).

In Fig. 5 the polarization for a 'typical' event from the April-May swarm is compared with that of a 'typical' post-September event: the polarization analysis had similar rectilinearity and azimuth but different dip angles, i.e. greater for the latter, indicating shallower events.

Other events characterizing the seismicity since late 2007 were impulsive, often high amplitude, deep and recurrently followed by episodes of harmonic tremor, lasting for several minutes up to several hours (Fig. 6). Harmonic tremor episodes commonly exhibited a fundamental frequency $\mathrm{f}_{1}$ between 1.5 and $3 \mathrm{~Hz}$ (as recorded by $1 \mathrm{~Hz}$ instruments) with up to 8 harmonics (but normally 3 to 4 ); gliding (proportional shifting of all spectral peaks) was commonly observed. The fundamental frequency $\mathrm{f}_{1}$ was the same for all recording stations, indicating that it was a source and not a path or site effect. The frequencies of the overtones were observed to be slightly shifted with respect to $\mathrm{n} \times \mathrm{f}_{1}$.

Polarization analyses were performed separately for the impulsive part of the sequence (frequency band $0.8-1.8 \mathrm{~Hz}$ ) and the tremor $\left(2.4-3.1 \mathrm{~Hz}\right.$, to include the fundamental frequency $\mathrm{f}_{1}$ ). The initial impulsive high frequency signal showed very high rectilinearity $(\mathrm{R} \sim 1)$, azimuth pointing slightly north of the West crater and very low dip angle ( $\sim 0$ at onset, therefore approaching the vertical below the station): those values indicated a deep source for these signals, located below the crater area. Particle motion analysis revealed a very short window of longitudinal polarization, pointing, again, slightly north of the crater area, while the following phases depicted clear transverse motion, continuously rotating with time. This observation was confirmed by the azimuth angles obtained by polarization analysis. Dip angles were found between 70 and $90^{\circ}$, when they were paralleled by high rectilinearity values (approaching 1 ). 


\section{4-05-2007 02:59:05}
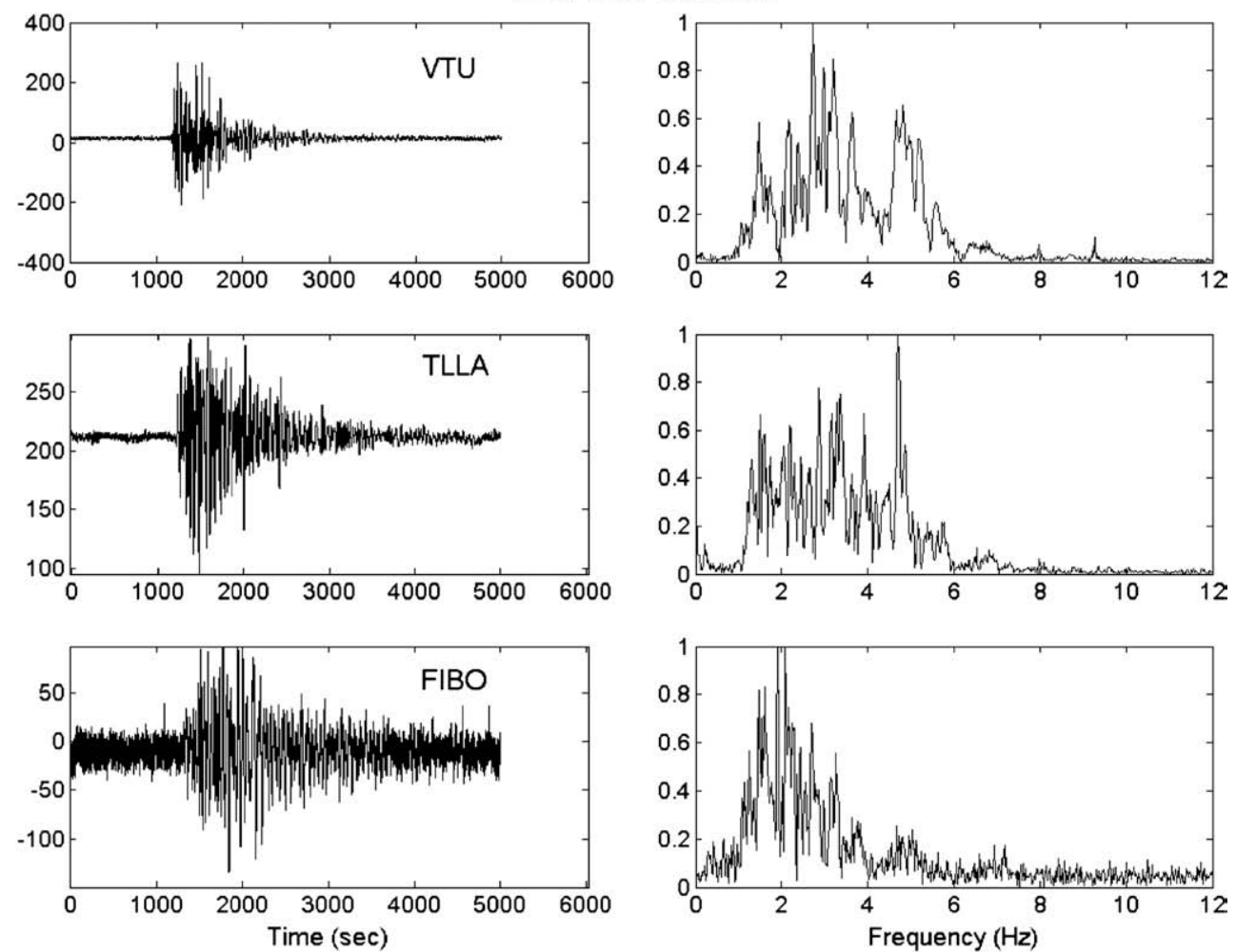

Fig. 4. Seismic event, interpreted as a VT type, recorded in May 2007 by the OVSICORI-UNA permanent network. The signal (left) and its frequency spectrum (right) are shown for the stations VTU, in the crater (top), and TLLA (middle) and FIBO (bottom), located at progressively higher distance from the crater area (Fig. $3 a$ ). The signal onset becomes progressively more emergent and the recordings loose the higher frequencies.

\subsection{Ground deformation}

Tilt measurements revealed no ground deformation above detection limits until 1996. Dry tilt measurements carried out at 'La Silvia' station, located at $2.5 \mathrm{~km} \mathrm{~W}$ of the volcano summit, showed an accumulated radial inflation of $2.3 \mu \mathrm{rad}$ between October 1996 and January 1999 (Barboza et al., 2003a,b). These authors also reported an average extension of $5 \mathrm{~cm}$ measured between 2001 and 2002 of the EDM lines from the summit to two points on the SW flank, at 0.8 and $2.9 \mathrm{~km}$ distance.

The summit network was set to measure distances from a pillar located on the southern rim of the Central Crater (Point Pilar at the touristic lookout point, Fig. 7a) to six fix prisms placed in the Central Crater and on the rims of the West, Central and East craters. In Fig. 7b the data collected from 2006 to 2008 are shown. Loss of several reflectors by vandalism affected some of the lines: the points available indicated lengthening of the distances from late 2006 to mid 2007, reversed to shortening in late 2007 and early 2008.

The second EDM network is located on the western flank of the summit cone, where distances were measured from the foot of the 600 m-high summit cone (point called Virtud, Fig. 8) to three reflectors located at different elevations (Poste, Lucas and Cima, Fig. 8). The distance between the Virtud and CIMA stations experienced shortening from early 2006 to 2007, reversed to lengthening in 2008, while the two 0.8 and $2.9 \mathrm{~km}$ long lines to the two points on the SW flank did not record any significant changes (Fig. 8). Both networks had the limitation of being very near or within the summit region and thus well inside the area of expected ground deformation in case of intrusion (this poses some limitations in absolutely quantifying the deformation). The Virtud station is at a distance of $\sim 3 \mathrm{~km}$ from the volcano summit. Models by Mogi (1958) and Yokoyama (1971) indicated that the maximum deformation was expected at comparable horizontal distance from the deformation source (Fig. 9, example for source depth of $4.5 \mathrm{~km}$ ).

Moreover, the lack of fixed reference points within the networks prevented a full characterization of the differential displacements that were detected. Nevertheless, a first general interpretation could infer a possible inflation trend prior to 2007 followed by steady deflation to present, although a large inflation after 2007 could render similar EDM results.

Tilt data measured since 2002 are shown in Fig. 10 together with the temperature in the vault; for the sake of clarity a zoom on the data from 2006 to 2008 is also plotted. The orientation of the tiltmeter (tilt towards the summit) was such that deflation was recorded as an increase of tilt. The data are uncorrected for the daily day/night variations of temperature but their influences were reduced by using the daily average of the tilt values. As mentioned earlier, temperatures at the vault changed of only $3.5^{\circ} \mathrm{C}$ over several years, with daily variation of less than one degree.

The tilt pattern from 2002 to 2008 suggested the occurrence of three distinct trends: 1) deflation from 2002 to March 2005; 2) inflation from March 2005 to late August 2007, marked by two deflation pulses, sometime in 2006 (data lost due to sabotage of the station) and in mid February 2007; 3 ) deflation from late August 2007, with an increase in the rate of deflation since late March 2008. Unfortunately, the data gathered only from one tiltmeter were not sufficient to uncompromisingly define volcanic deformation.

Data from four GPS campaigns were available to the present work. Two initial campaigns were performed in 2006 and 2007 using as benchmarks the points marked TUR3, 4, 5 and 8 in Figs. 3b and 11. Measurements were taken by GNSS Trimble mono-frequency receivers, over short occupations. Two further campaigns were performed in 2008 using GNSS Leica 1200 double frequency receivers, for a 3 hour-long and a $>8$ hour-long occupation, respectively. 
a)
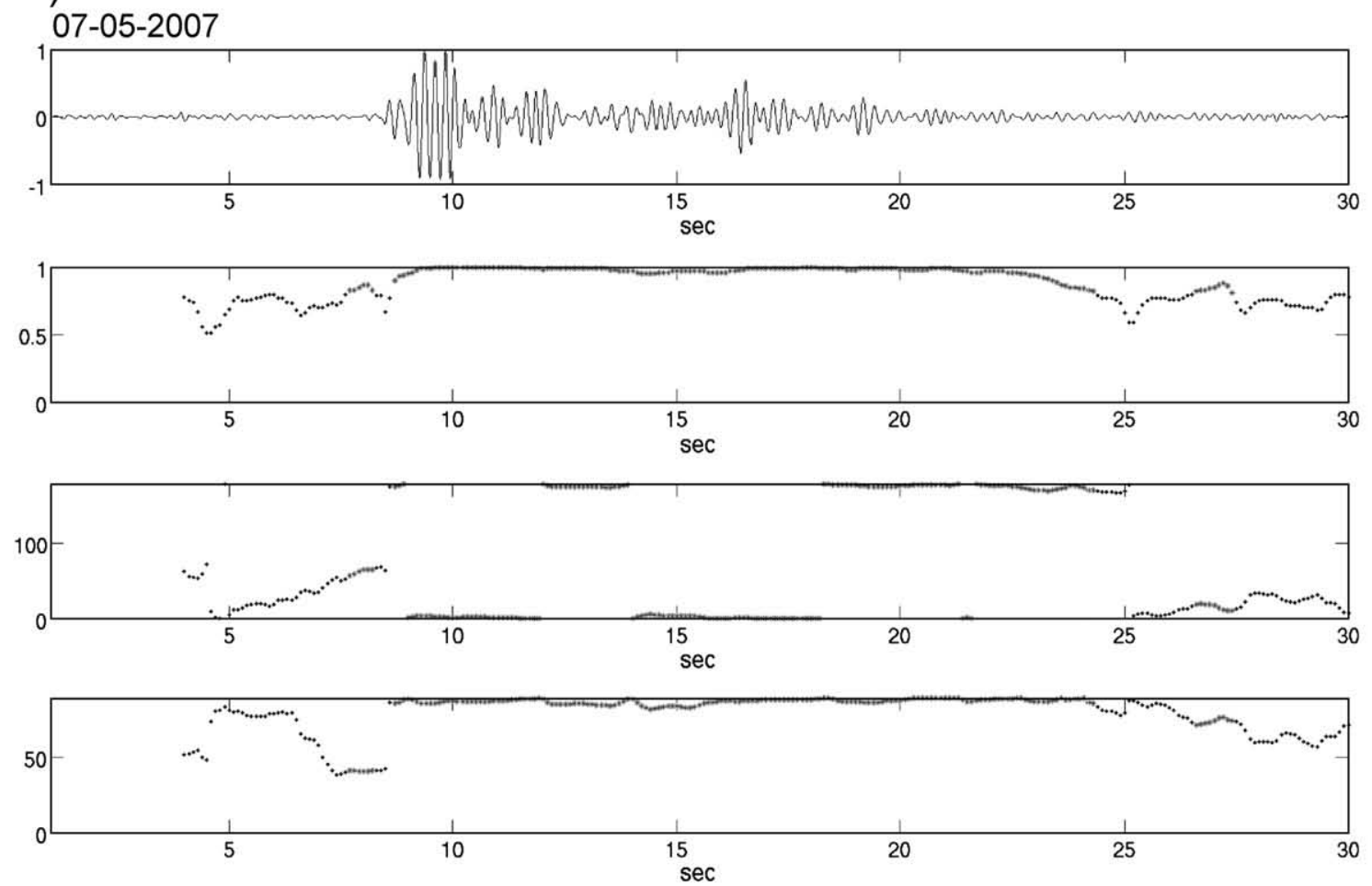

b)

\section{0-04-2008}
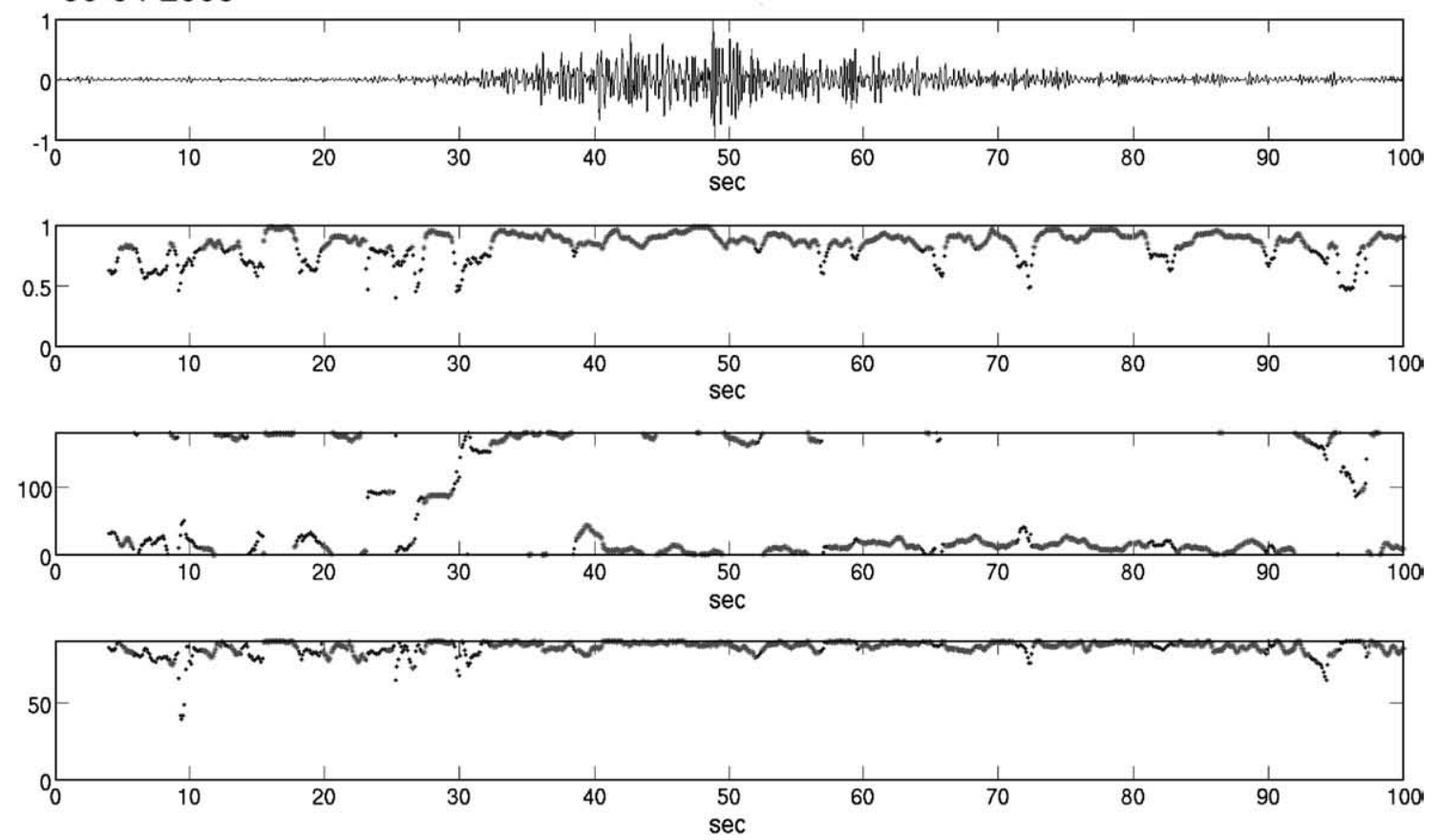

Fig. 5. Polarization analysis for events recorded at the three component station PICA, in a) May 2007 and b) April 2008. For each event, waveform, rectilinearity, azimuth and dip angles are shown (from top to bottom), as calculated following the method of Kanasevich (1981).

Helmert's transformation (Chen and Hill, 2005) and a 3-D adjustment method (Muller et al., 2009) were applied in order to compare the data from such different campaigns and obtain the total displacement vectors for the entire period 2006 to 2008. Moreover, starting in May 2008, the Virtud station, used as base station for EDM measurements (Fig. 8), was occupied within the GPS survey in order to check its stability and therefore the validity of the data obtained by the EDM networks. The resulting vectors are shown in Fig. 11 together with an average error ellipsoid. They indicated outward displacement and a possible inflation from 2006 to February 2008. Tentatively, the trend was maintained from February to May 2008.

The levelling across the Ariete fault did not highlight significant changes during the repeated occupations, in agreement with the lack of clear seismic activity from the fault since the network was established. 

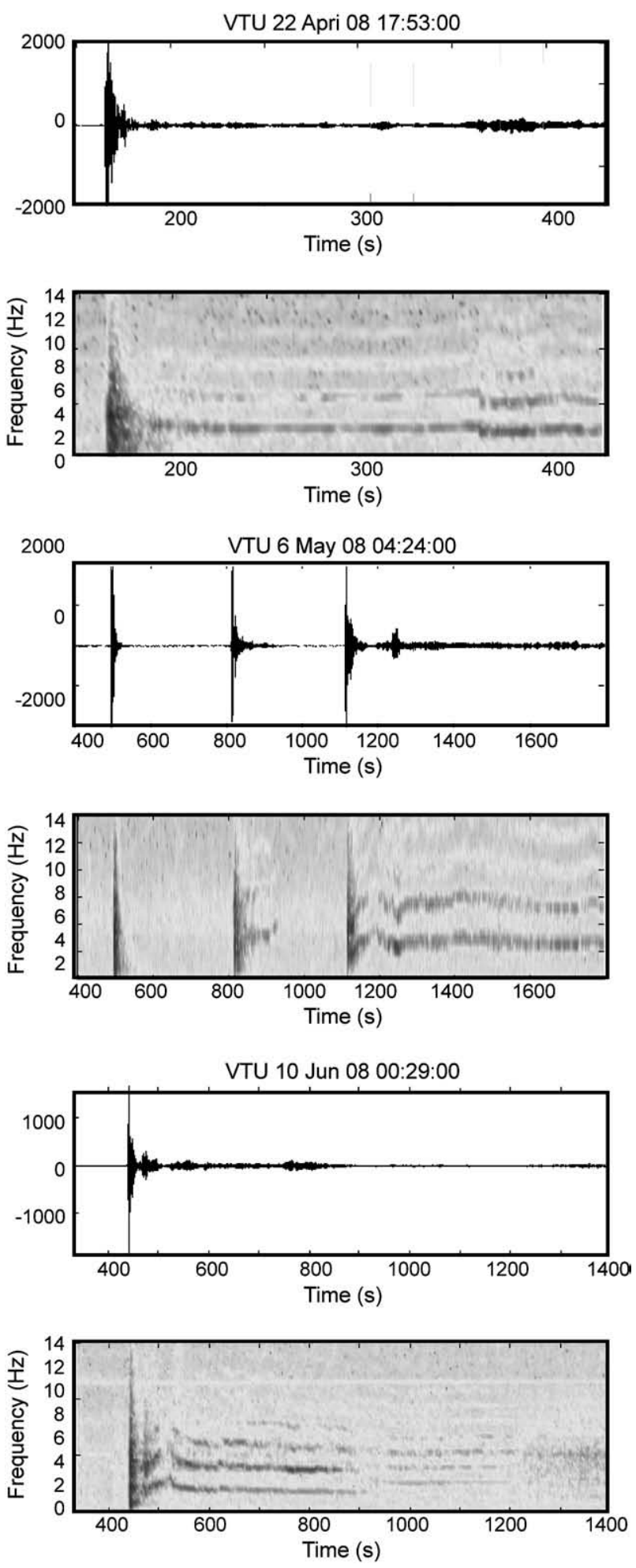

Fig. 6. Post-2007 seismicity: Three examples of harmonic tremor sequences recorded at station VTU in early 2008. For each event, the waveform and its spectrogram are shown.

\subsection{Geochemistry of fumarolic discharges}

The two small, low-flux fumarolic fields in the inner SW flank of the Central crater and in the northern rim of the West crater, respectively, prior to 2000 (Tassi et al., 2004; Vaselli et al., 2009) were characterized by outlet temperatures $\sim 90^{\circ} \mathrm{C}$ and a chemical composition marked by dominant $\mathrm{H}_{2} \mathrm{O}$ and $\mathrm{CO}_{2}$, relevant $\mathrm{H}_{2} \mathrm{~S}, \mathrm{~N}_{2}, \mathrm{HCl}$ and $\mathrm{H}_{2}$ concentrations and minor amounts of $\mathrm{HF}, \mathrm{CO}$ and $\mathrm{CH}_{4}$. Such chemical features are considered typical of fluids produced by gas-water-rock interactions occurring within a well-developed hydrothermal reservoir (Giggenbach, 1987, 1996). However, the He isotopic signature (R/ $\mathrm{Ra}=7.3$, where $\mathrm{R}$ is the ${ }^{3} \mathrm{He} /{ }^{4} \mathrm{He}$ ratio in the sample and $\mathrm{Ra}$ is the ${ }^{3} \mathrm{He} /$ ${ }^{4} \mathrm{He}$ ratio in the air, i.e. $1.39 \times 10^{-6}$, (Mamyrin and Tolstikhin, 1984)), closely resembling that of mantle-related He in subduction zones (Poreda and Craig, 1989), suggested that a magmatic source was still active at the Turrialba volcano (Hilton et al., 2002; Shaw et al., 2003; Tassi et al., 2004). In November 2001 a drastic compositional change, mainly consisting in the appearance of $\mathrm{SO}_{2}$, affected the fumarolic fluids of the Central crater. Sulphur dioxide is a diagnostic component of high temperature fumaroles directly related to magmatic degassing (Gerlach and Nordlie, 1975; Giggenbach, 1987). Therefore, this event marked the beginning of a new phase of the fumarolic activity of the volcano, which led to further changes of the fluid chemistry and fumarolic degassing rate. In April 2002, a $4 \mathrm{~m}$ wide fracture discharging fluids at $90{ }^{\circ} \mathrm{C}$ (Quemada fracture) opened between the West and the Central craters, and new fumarolic vents opened in the $\mathrm{N}$ and $\mathrm{S}$ outer flanks of the West crater and within the Central crater (Tassi et al., 2004), discharging fluids chemically similar to those from the West and Central craters. In June 2005 new fumaroles with outlet temperatures $\sim 90^{\circ} \mathrm{C}$ formed along the NE-SW-oriented Ariete fault system in the southern external flank of the volcanic edifice, at an elevation of 2700 and $2600 \mathrm{~m}$. Fluids discharged from these sites showed no presence of high temperature gas compounds, but the mantle signature of the He isotopic values $\left(R / R_{\text {air }}=7.7\right)$, argued for a common deep source feeding both the crater and distal gas discharges. In 2007, the fumarolic activity from the summit craters showed a further increase, and in February 2008 a temperature of $282^{\circ} \mathrm{C}$, the highest recorded at Turrialba volcano (Cheminée et al., 1982), was measured at a high-flux fumarole located at the bottom of the West crater (Vaselli et al., 2009). This intense fumarolic activity of 2007-2008 resulted in a volcanic plume up to $2 \mathrm{~km}$ high that was occasionally visible from San Josè (OVSICORI-UNA, 2007, 2008).

The evolution of the fumarolic fluid chemistry recorded at both the West and the Central fumaroles in 1998-2008 could satisfactorily be described by the temporal patterns of the $\mathrm{SO}_{2} / \mathrm{CO}_{2}, \mathrm{HCl} / \mathrm{CO}_{2}$ and $\mathrm{HF} /$ $\mathrm{CO}_{2}$ ratios at the monitored fumaroles of the West (Fig. 12a) and Central (Fig. 12b) craters, where distinct phases were distinguished: 1) a hydrothermal stage in 1998-2001,2) a magmatic-related fluid input at the end of 2001,3) a progressive increase of the magmatic signature in 2002-2007, and, more drastically, in 2007-2008.

According to the temporal trends of the main gas compounds, the $\delta \mathrm{D}$ and $\delta^{18} \mathrm{O}$ values in the steam prior to 2005 depicted an evaporation trend related to the boiling of an aquifer fed by meteoric water, whereas those of samples collected after 2005 showed a mixing trend between a meteoric and an "andesitic" (Taran et al., 1989; Giggenbach, 1992) endmember (Vaselli et al., 2010).

The temporal pattern of the $\mathrm{pH}$ values measured in condensates from the monitored fumaroles of the West crater from 1992 to 2008 (Table 1), is consistent with the chemical evolution of the gas composition, showing a decreasing trend that started in 2001 and became more pronounced after 2004 (Fig. 13).

\section{4. $\mathrm{SO}_{2}$ flux}

Mini-DOAS profiles were carried out at irregular intervals since 2002 in the surroundings of the summit craters. Data from a profile NW to W and SE of the west crater rim measured in 2002 and 2007 displayed an increment from 1 to $\sim 70$ ton/day of $\mathrm{SO}_{2}$ over the considered period. The $\mathrm{SO}_{2}$ flux rates in January 2008 are of one order of magnitude higher. Unfortunately, the available data are sparse and likely affected by the fact that the 2008 profile was not measured at the same location as the previous ones, but approximately $2.5 \mathrm{~km}$ to the SW. At the time of writing, the four permanent mini-DOAS stations installed in April 2008 were still undergoing proper 


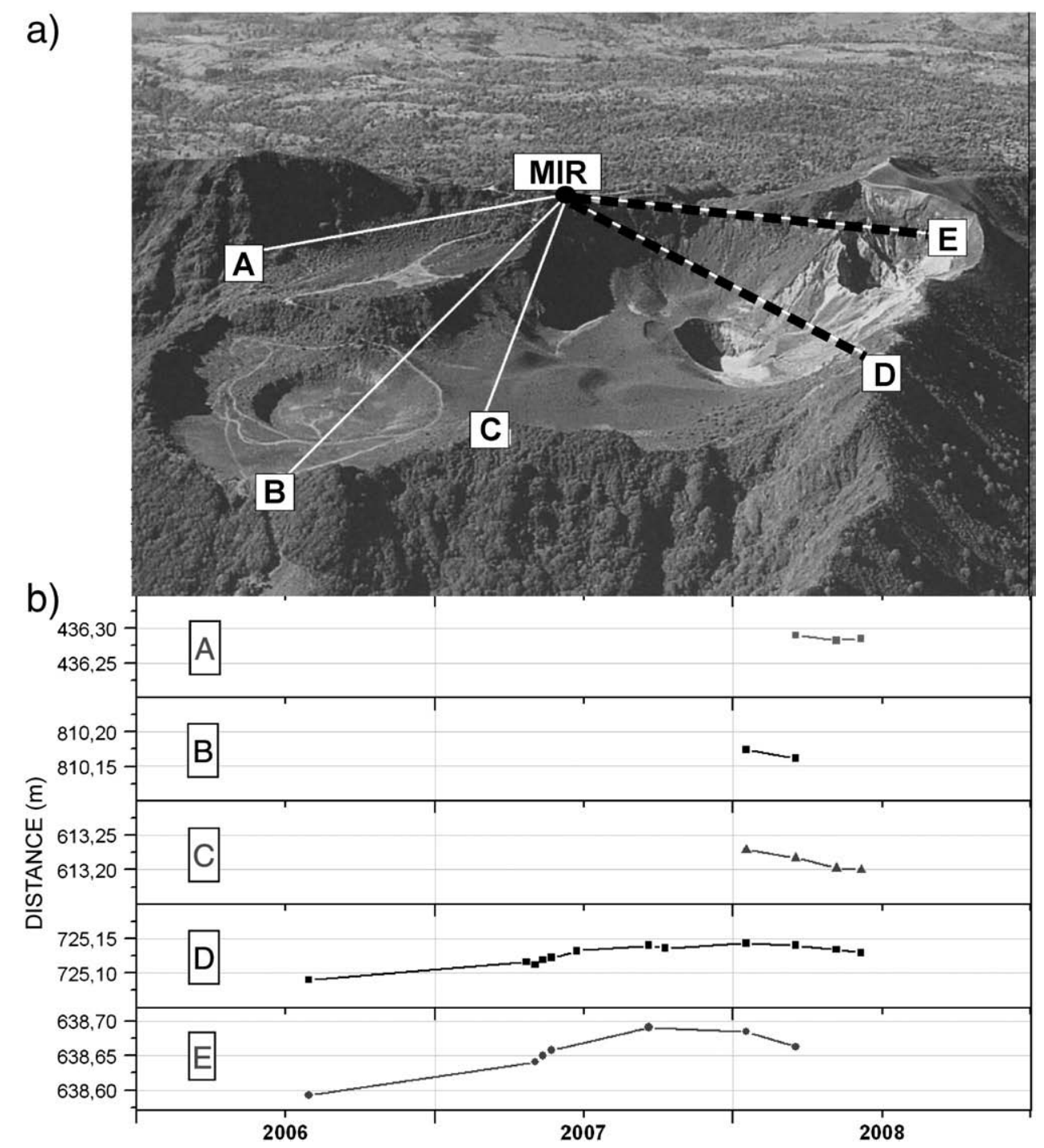

Fig. 7. a) The summit EDM network which measures distances from a pillar located at the southern rim of the Crater Area (at MIR, the Touristic Mirador) to five prisms located into and on the rims of the Western, Central and Eastern craters (Points A, B, C, D, and E); b) data collected from 2006 to 2008. Loss of several reflectors by vandalism affected some of the lines.

calibration. The measured, though not validated, values indicated that the $\mathrm{SO}_{2}$ fluxes were ranging between 700 and $1100 \mathrm{t} /$ day (S. Miranda Brenes, Pers. Comm.).

\subsection{Radon emission}

Radon flux data collected from late 1997 to 2007 are shown in Fig. 14. No significant variations were observed in the pre-1997 records, with the Radon values constantly $<200 \mathrm{~Bq} / \mathrm{m}^{3}$. The Radon contents (in $\mathrm{Bq} / \mathrm{m}^{3}$ ) displayed a significant increase from 1997 to 2000 at La Silvia (up to $1700 \mathrm{~Bq} / \mathrm{m}^{3}$ ) and La Fuente (up to $1200 \mathrm{~Bq}$ / $\mathrm{m}^{3}$ ) stations, located at 3 and $5 \mathrm{~km}$ from the summit, respectively, and coeval with the previously mentioned precursory seismic pulses. Conversely, the Rn contents at Los Quemados station remained substantially unmodified. In 2002 the Radon values drastically decreased and were clustering around those measured prior 1997 $\left(<200 \mathrm{~Bq} / \mathrm{m}^{3}\right)$.

\subsection{Rainwater}

The temporal variations of the $\mathrm{SO}_{4} / \mathrm{Cl}$ ratios and the $\mathrm{SO}_{4}, \mathrm{Cl}$ and $\mathrm{F}$ contents along with those of the electrical conductivity and the $\mathrm{pH}$ values for the rainwaters collected at the rim of the West crater
(Fig. 3c) from 2003 to mid 2008 are shown in Fig. 15. The temporal profiles of the selected physical-chemical parameters define a significant change in early 2005 : the $\mathrm{pH}$ values significantly decreased down to 2, while the electrical conductivity and $\mathrm{SO}_{4}, \mathrm{Cl}$ and $\mathrm{F}$ concentrations increased up to two orders of magnitude, reaching their maximum values between the second half of 2007 and first half of 2008 (up to $4730 \mathrm{mS} / \mathrm{cm}, 690,180$ and $22 \mathrm{mg} / \mathrm{L}$, respectively). It is noteworthy to point out how the $\mathrm{SO}_{4} / \mathrm{Cl}$ ratios, following the general increase after 2005, displayed the highest values (up to 876), though characterized by strong variations, until middle 2007. Successively, this ratio decreased to the lowest values ever recorded and clustering just slightly above 0 . The apparent contradiction with respect to what observed for the fumarolic gases may be related to the fact that the condensation process does not allow $\mathrm{SO}_{2}$ to be completely dissolved as $\mathrm{SO}_{4}^{2-}$ since different intermediate, relatively stable products, such as $\mathrm{SO}_{3}^{2-}, \mathrm{HS}^{-}$and so forth, can be formed. Thus, the condensate solution has to be oxidized with $\mathrm{H}_{2} \mathrm{O}_{2}$ (not performed in this work) prior the analysis by ion-chromatography. Furthermore, significant contributions from the dissolution of $\mathrm{H}_{2} \mathrm{~S}$ cannot be ruled out.

The Costa Rican Institute of Electricity (Instituto Costarricense de Electricidad, ICE) monitors the acid rains in the area in order to assess at which degree they may affect the existing infrastructure on the volcano. ICE has placed seventeen fixed collection sites on the volcano 


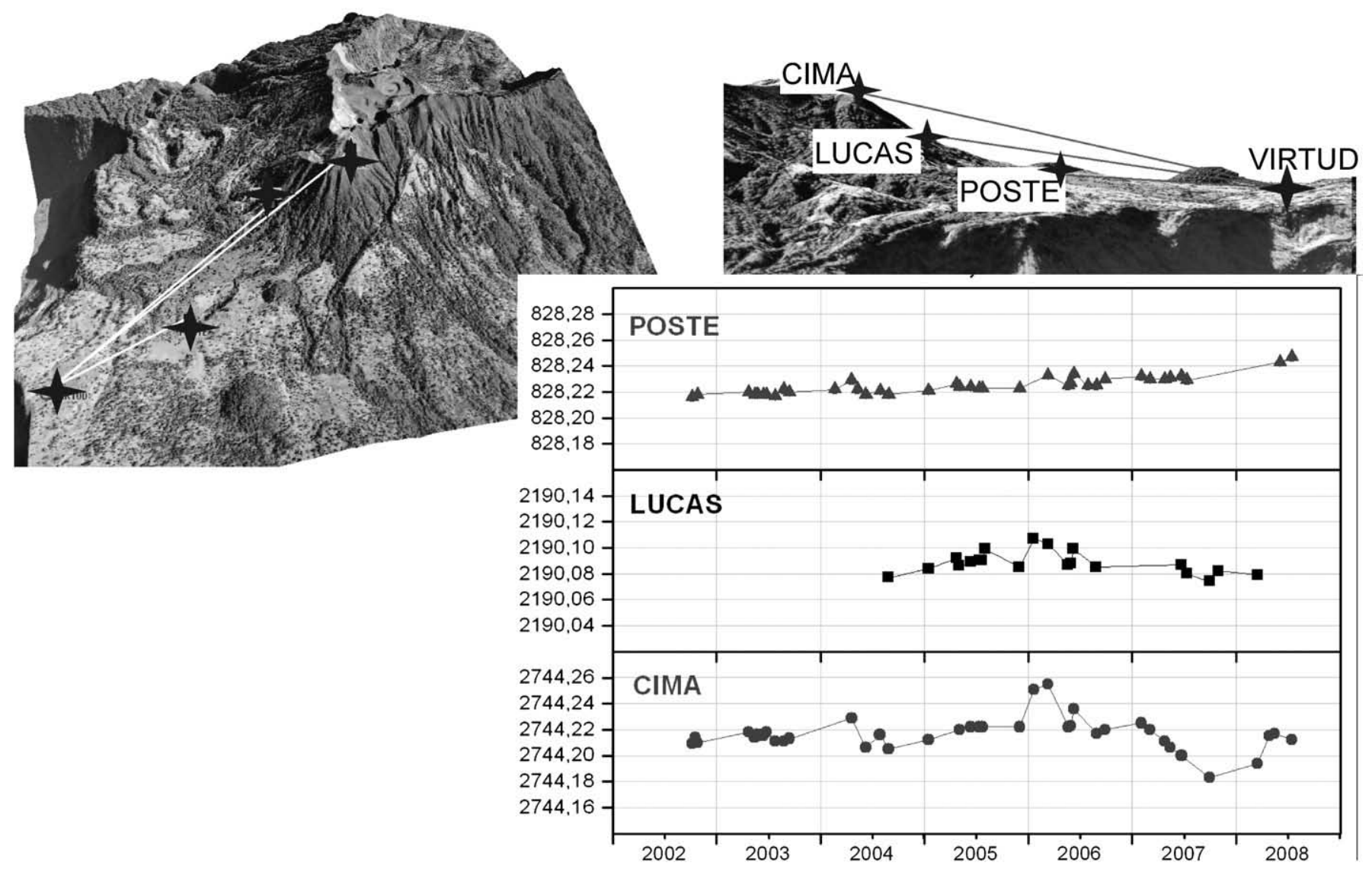

Fig. 8. EDM network on the western flank of the summit cone: distances are measured from the foot of the 600 m-high summit cone (point called Virtud) to three reflectors located at different elevations (Poste, Lucas and Cima). Data collected from 2002 to early 2008 are shown.
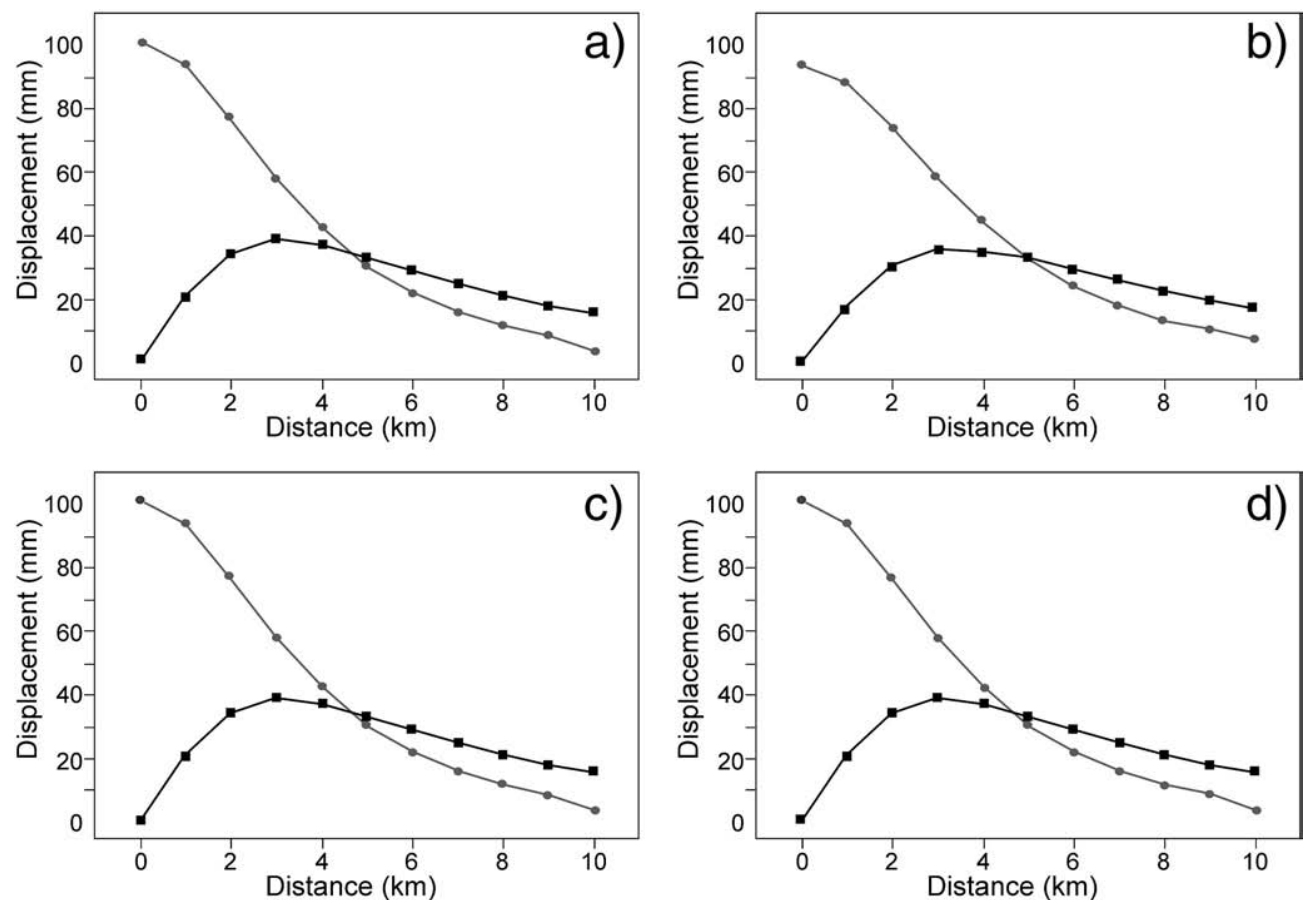

Fig. 9. Modelling vertical (circle) and horizontal (square symbol) deformation due to a spherical source at different depths: a) Yokoyama (1971) model for a source depth at 4.5 km, pressure = $3.0 \mathrm{kbar}$; b) Mogi (1958) model for a source depth of $5 \mathrm{~km}$, pressure $2.5 \mathrm{kbar}$; c) Mogi (1958) model for a source depth of $4.5 \mathrm{~km}$, pressure $3.0 \mathrm{kbar}$; d) Mogi (1958) model for a source depth of $4 \mathrm{~km}$, pressure $2.5 \mathrm{kbar}$. 


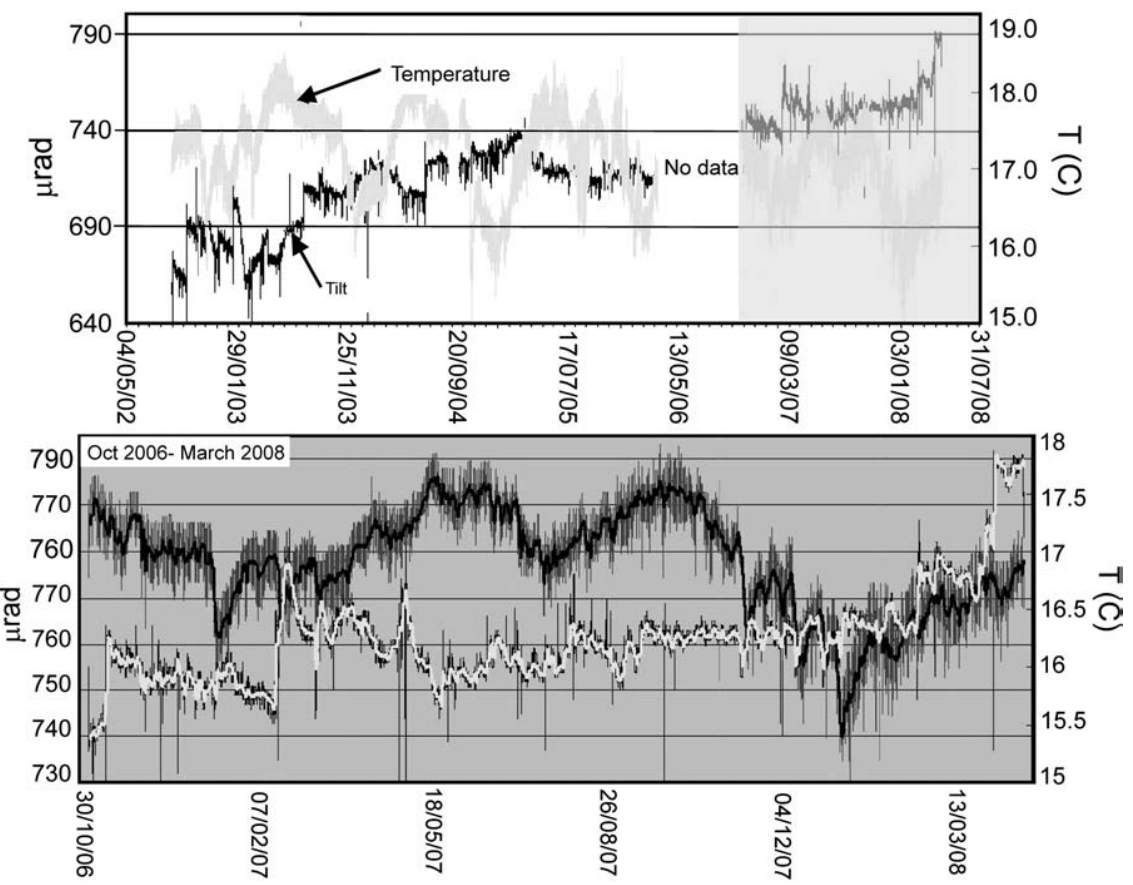

Fig. 10. An electronic tiltmeter operating since 2002 on the SW flank of Turrialba, about $1.6 \mathrm{~km}$ from the crater summit (indicated by white star in Fig. $3 \mathrm{~b}$ ). Data from 2002 to early 2008 are shown (top); data from late 2006 are zoomed in (bottom plot). The tilt data are plotted together with the temperature measured in the vault. The data are not corrected for the influence of the daily variations in the temperatures between day and night, although this effect was reduced using the daily average of the tilt values. (Data courtesy of Marino Protti).

edifice, mainly concentrated on the W, SW and S flanks. Iso-acidity maps are produced on a monthly basis and are available at http:// www.rsn.geologia.ucr.ac.cr/Vulcanologia/volcanturrialba.html. These maps allow a prompt visualization of the rapid extension of the area affected by acid rain towards SW. For example, in August 2007 the area with $\mathrm{pH}<5.6$ rainwater extended up to $2.3 \mathrm{~km}$ from the crater. In the same area $\mathrm{pH}$ values of $\sim 4$ were measured in November and early December 2007. More acidic values $(\mathrm{pH} \sim 3)$ were recorded early

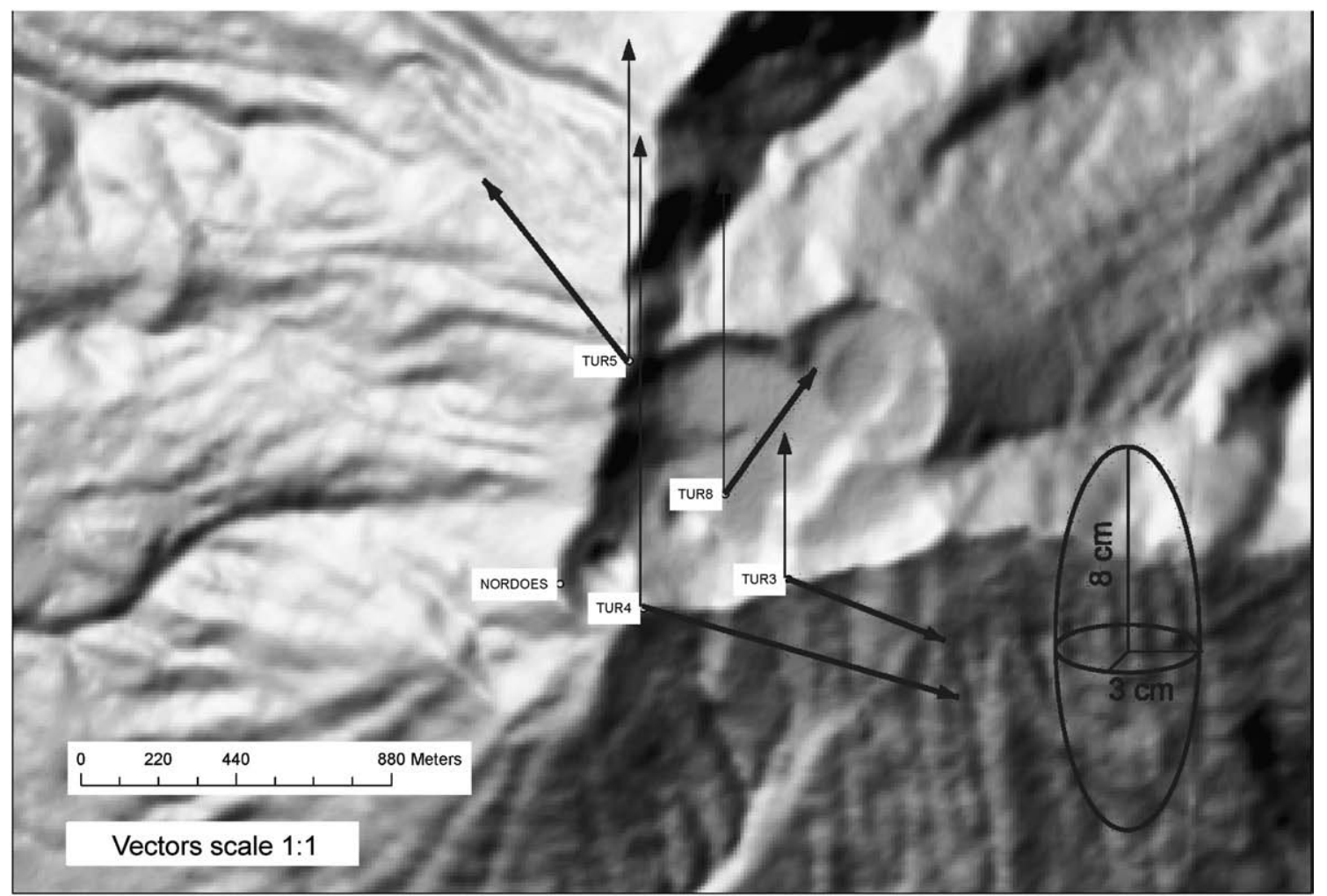

Fig. 11. Total displacement vectors for the entire period 2006 to 2008, obtained by 3-D adjustment (Muller et al., 2009) of GPS data collected during four different campaigns performed between 2006 and 2008. 

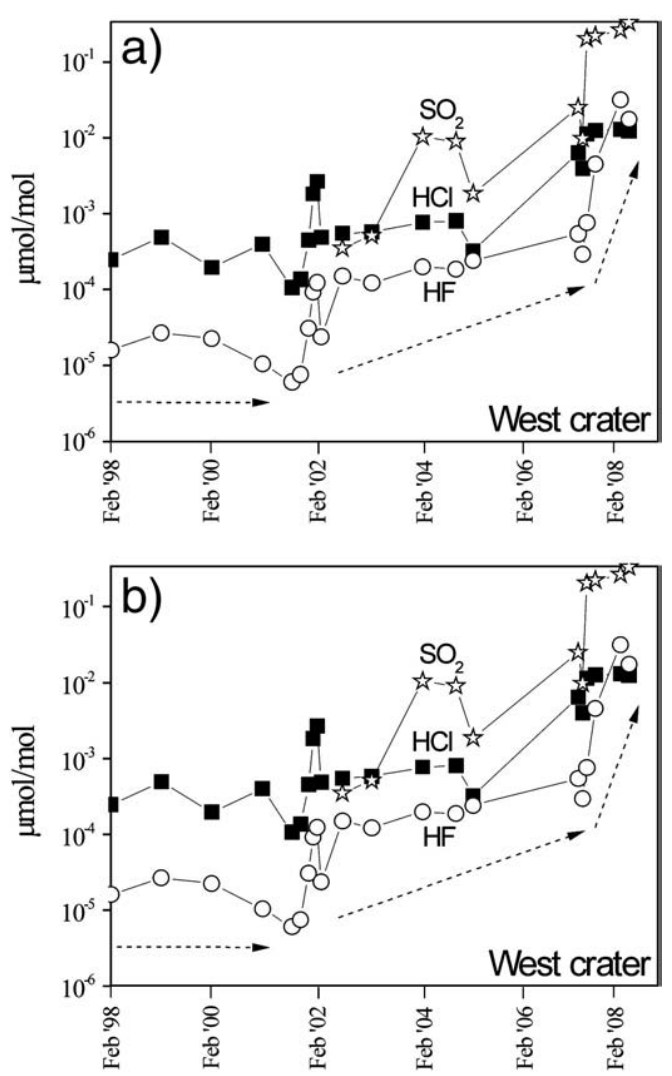

Fig. 12. $\mathrm{SO}_{2} / \mathrm{CO}_{2}, \mathrm{HCl} / \mathrm{CO}_{2}$ and $\mathrm{HF} / \mathrm{CO}_{2}$ ratios at the monitored fumaroles of the West (a) and Central (b) craters.

2008, while $\mathrm{pH} \sim 5$ was measured for those samples collected at $\sim 4.5 \mathrm{~km} \mathrm{SW}$ of the crater (Soto et al., 2008). An illustrative exemplification of this evolution is sketched in Fig. 16.

\subsection{Effect on the environment}

The enhanced gas discharge observed in 2007-08 has caused significant interference on tropospheric $\mathrm{O}_{3}$ measurements at $2-3 \mathrm{~km}$ altitude, $\sim 50 \mathrm{~km}$ west of the volcano, detected by the Ozone Monitoring Instrument (OMI) mounted on the NASA EOS-Aura Satellite (http://so2.umbc.edu/). The interaction of the acid gases (mainly $\mathrm{SO}_{2}$ and $\mathrm{Cl}$ ) with humidity in the atmosphere favours the precipitation of acid rain, mainly in the west sector of the volcanic edifice, due to the predominant winds coming from the Caribbean (EENE to W-WSW). As a consequence, the vegetation and the infrastructures below the volcanic plume (http://www.ovsicori.una. ac.cr/vulcanologia/Volcan_Turrialba.htm) have been strongly affected. In 2008, soil $\mathrm{CO}_{2}$ flux measurements (accumulation chamber method; Chiodini et al. (1998)) were carried out on the flanks of the SW sector of the volcano, where vegetation was showing clear signs of suffering. The observed effects range from foliage discolouring to death for plants of different native and introduced arboreal species, annual cultures (onion, potatoes) and pastures. Moreover, cattle and other animals were severely affected with strong consequences on the local economy (for example, cheese production, which is one of the major sources of income for the local population). The lack of significant $\mathrm{CO}_{2}$ flux anomalies from the soil (M. L. Carapezza, F. Barberi and T. Ricci, Pers. Comm.) had undoubtedly proven that acidic rain was the main cause of the damage on the biota of the area. While the effects of this phenomenon on human health are to be properly assessed, a large percentage of the local population has left the area, due to the unacceptable living conditions.
Table 1

$\mathrm{pH}$ values measured in condensates from the monitored fumaroles of the West crater from 1992 to 2008; n.d.: not determined.

\begin{tabular}{|c|c|c|c|c|c|}
\hline Date & $\mathrm{pH}$ & Date & $\mathrm{pH}$ & Date & $\mathrm{pH}$ \\
\hline 14/01/1992 & 4.80 & $19 / 10 / 2001$ & 2.60 & $23 / 03 / 2007$ & 1.20 \\
\hline 13/04/1993 & 4.20 & $17 / 01 / 2002$ & 3.30 & $24 / 04 / 2007$ & 1.37 \\
\hline 27/04/1994 & 3.70 & $01 / 02 / 2002$ & 2.95 & 09/05/2007 & 1.47 \\
\hline 14/03/1995 & 4.65 & $19 / 02 / 2002$ & 3.05 & $18 / 05 / 2007$ & 1.31 \\
\hline 01/09/1995 & 4.00 & $21 / 03 / 2002$ & 3.60 & $23 / 05 / 2007$ & 1.44 \\
\hline 12/01/1996 & 3.60 & $29 / 05 / 2002$ & 5.75 & $26 / 01 / 2005$ & 3.07 \\
\hline $17 / 07 / 1996$ & 4.10 & $14 / 11 / 2002$ & 2.65 & $04 / 03 / 2005$ & 2.48 \\
\hline 06/11/1996 & 4.35 & 09/01/2003 & 3.50 & $02 / 04 / 2005$ & 2.79 \\
\hline 09/04/1997 & 4.35 & $01 / 05 / 2003$ & 2.73 & $11 / 04 / 2005$ & 3.37 \\
\hline $14 / 01 / 1998$ & 4.05 & 09/05/2003 & 3.80 & $22 / 04 / 2005$ & 2.21 \\
\hline 03/03/1998 & 4.20 & $29 / 05 / 2003$ & 3.30 & $07 / 06 / 2005$ & 2.65 \\
\hline 22/04/1998 & 4.10 & $26 / 06 / 2003$ & 2.80 & $23 / 06 / 2005$ & 2.23 \\
\hline 22/07/1998 & 4.75 & $23 / 07 / 2003$ & 3.00 & $12 / 07 / 2005$ & 2.06 \\
\hline 17/11/1998 & 4.20 & $01 / 08 / 2003$ & n.d. & $22 / 08 / 2005$ & 2.45 \\
\hline 15/03/1999 & 6.05 & $08 / 08 / 2003$ & 3.30 & 09/09/2005 & 2.76 \\
\hline 28/04/1999 & 4.45 & $28 / 08 / 2003$ & 2.60 & 03/10/2005 & 2.43 \\
\hline 10/06/1999 & 3.65 & $11 / 09 / 2003$ & 3.40 & $04 / 11 / 2005$ & 2.13 \\
\hline 06/08/1999 & 3.80 & $25 / 09 / 2003$ & 3.25 & $06 / 12 / 2005$ & 2.25 \\
\hline 23/09/1999 & 3.50 & $17 / 01 / 2004$ & 3.30 & $24 / 01 / 2006$ & 2.05 \\
\hline 15/10/1999 & 3.75 & $30 / 01 / 2004$ & 3.50 & $21 / 02 / 2006$ & 2.39 \\
\hline 26/11/1999 & 3.15 & $24 / 02 / 2004$ & 3.70 & $15 / 03 / 2006$ & 2.38 \\
\hline 01/02/2000 & 5.20 & 09/03/2004 & 3.96 & 02/05/2006 & 1.97 \\
\hline $18 / 02 / 2000$ & 4.15 & $31 / 03 / 2004$ & 3.29 & $18 / 05 / 2006$ & 1.31 \\
\hline $27 / 02 / 2000$ & 6.25 & $23 / 04 / 2004$ & 2.60 & $23 / 05 / 2006$ & 1.44 \\
\hline $07 / 04 / 2000$ & 3.10 & $04 / 05 / 2004$ & 0.73 & $13 / 06 / 2006$ & 2.01 \\
\hline 02/06/2000 & 3.85 & 03/06/2004 & 3.43 & $26 / 01 / 2007$ & 1.18 \\
\hline $05 / 07 / 2000$ & 4.65 & $12 / 08 / 2004$ & 2.77 & $23 / 03 / 2007$ & 1.20 \\
\hline 09/08/2000 & 4.50 & $13 / 08 / 2004$ & 2.78 & $24 / 04 / 2007$ & 1.37 \\
\hline 08/09/2000 & 3.45 & 08/09/2004 & 2.78 & 09/05/2007 & 1.47 \\
\hline $27 / 10 / 2000$ & 3.35 & $11 / 10 / 2004$ & 2.74 & $18 / 05 / 2007$ & 1.31 \\
\hline $01 / 11 / 2000$ & 3.12 & $08 / 12 / 2004$ & 2.22 & $23 / 05 / 2007$ & 1.44 \\
\hline $02 / 11 / 2000$ & 2.55 & $26 / 01 / 2005$ & 3.07 & $19 / 06 / 2007$ & 1.74 \\
\hline $09 / 11 / 2000$ & 3.40 & 04/03/2005 & 2.48 & $23 / 06 / 2007$ & 1.85 \\
\hline $24 / 11 / 2000$ & 3.40 & $02 / 04 / 2005$ & 2.79 & $18 / 07 / 2007$ & 2.44 \\
\hline $20 / 12 / 2000$ & 2.85 & $11 / 04 / 2005$ & 3.37 & $16 / 08 / 2007$ & 1.28 \\
\hline $01 / 01 / 2001$ & 2.72 & $22 / 04 / 2005$ & 2.21 & 05/09/2007 & 1.24 \\
\hline 09/01/2001 & 2.50 & 07/06/2005 & 2.65 & $13 / 11 / 2007$ & 0.55 \\
\hline $16 / 01 / 2001$ & 2.20 & $23 / 06 / 2005$ & 2.23 & $05 / 12 / 2007$ & 0.65 \\
\hline $17 / 01 / 2001$ & 3.20 & $12 / 07 / 2005$ & 2.06 & $31 / 01 / 2008$ & 0.95 \\
\hline $28 / 01 / 2001$ & 3.45 & $22 / 08 / 2005$ & 2.45 & $27 / 02 / 2008$ & 1.03 \\
\hline $14 / 02 / 2001$ & 3.65 & 09/09/2005 & 2.76 & 07/03/2008 & 0.56 \\
\hline $01 / 03 / 2001$ & 3.87 & $03 / 10 / 2005$ & 2.43 & $02 / 05 / 2008$ & 0.69 \\
\hline $13 / 03 / 2001$ & 3.65 & $04 / 11 / 2005$ & 2.13 & $22 / 07 / 2008$ & 0.39 \\
\hline $23 / 03 / 2001$ & 4.95 & $06 / 12 / 2005$ & 2.25 & $02 / 10 / 2008$ & 0.77 \\
\hline $19 / 04 / 2001$ & 2.40 & $24 / 01 / 2006$ & 2.05 & $14 / 11 / 2008$ & 0.39 \\
\hline 03/05/2001 & 3.25 & $21 / 02 / 2006$ & 2.39 & $24 / 01 / 2009$ & 1.13 \\
\hline $06 / 06 / 2001$ & 4.05 & $15 / 03 / 2006$ & 2.38 & $24 / 03 / 2009$ & 0.90 \\
\hline $01 / 07 / 2001$ & 3.15 & $02 / 05 / 2006$ & 1.97 & $14 / 04 / 2009$ & 0.71 \\
\hline $04 / 07 / 2001$ & 3.50 & $18 / 05 / 2006$ & 1.31 & $17 / 05 / 2009$ & 0.22 \\
\hline $15 / 07 / 2001$ & 2.80 & $23 / 05 / 2006$ & 1.44 & $10 / 06 / 2009$ & 0.57 \\
\hline $17 / 08 / 2001$ & 2.85 & $13 / 06 / 2006$ & 2.01 & & \\
\hline 26/09/2001 & 2.95 & $26 / 01 / 2007$ & 1.18 & & \\
\hline
\end{tabular}

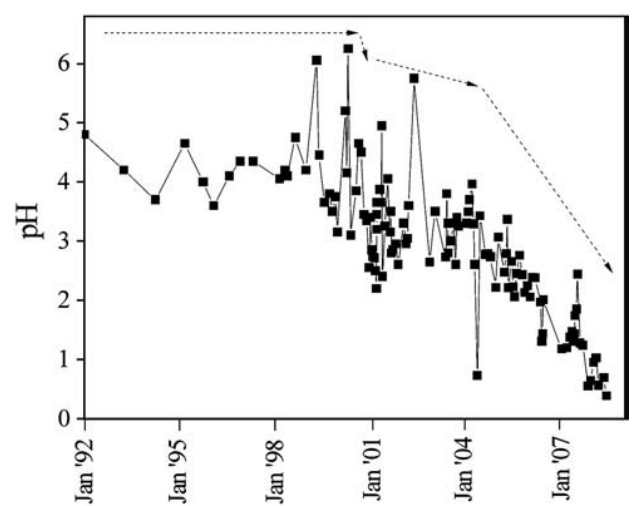

Fig. 13. $\mathrm{pH}$ values measured in condensates from the monitored fumaroles of the West crater from 1992 to 2008. 


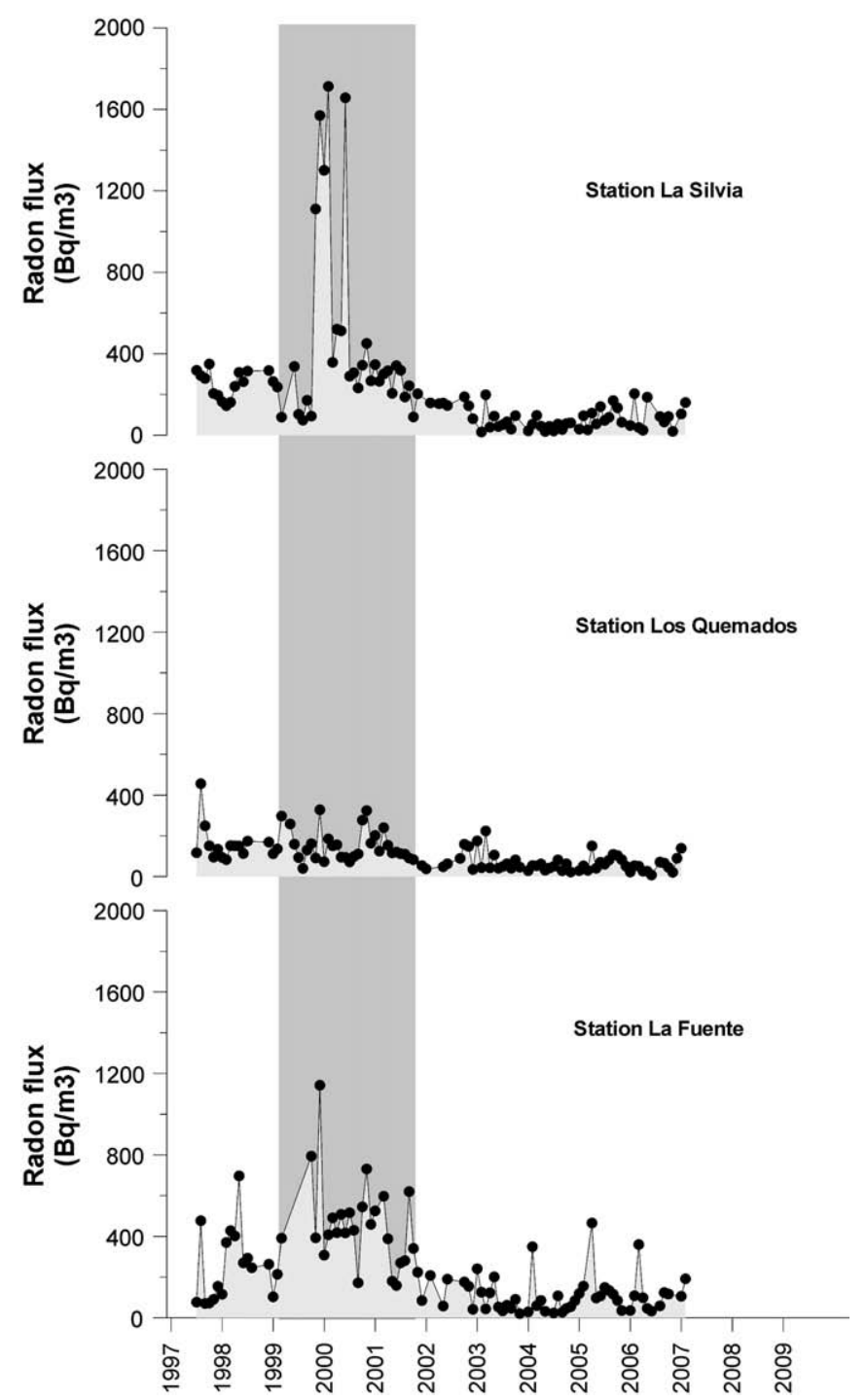

Fig. 14. Radon gas flux emission data, in $\mathrm{Bq} / \mathrm{m}^{3}$, collected at La Silvia (top), Los Quemados (centre) and La Fuente (bottom) stations between 1997 to early 2008. In grey, the time period where anomalous Rn concentrations were recorded.

\section{Discussion}

In the period of observation, spanning more than a decade, all the collected seismic and geochemical observations lead to similar conclusions, as also supported by the geodetical measurements. The data available from the 1990 to 2008 allow defining three main phases of activity at Turrialba volcano.

The first phase (1996-2000) was characterized by overall very low and constant seismicity levels and low fumarolic emission from the summit craters (Central and West). During this period, the magmatic fluids were completely scrubbed by the main hydrothermal reservoir that operated as an efficient buffer barrier for the juvenile gases released from the magma likely hosted at a depth of $<10 \mathrm{~km}$, as deduced by petrological data of the neighbouring Irazú volcano (Benjamin et al., 2007) and local earthquake tomography (Husen et al., 2003). As a consequence, only scarcely to low soluble acidic compounds, i.e. $\mathrm{CO}_{2}$ and $\mathrm{H}_{2} \mathrm{~S}$ could be retrieved at the fumarolic gas discharges. Nevertheless, the isotopic signature of carbon (in $\left.\mathrm{CO}_{2}\right)$ and particularly that of He marked a clear magmatic source (Tassi et al., 2004; Vaselli et al., 2010). A shallow aquifer, fed by the abundant rainfall of the area, helped maintaining the outlet temperature of the fumaroles at $<95{ }^{\circ} \mathrm{C}$. The low level of seismicity thus reflected the activity of the superficial hydrothermal system. Deformation data did not indicate any significant ground movement.

The seismic patterns changed after October 2000, with the appearance of several 'important' swarms containing hybrid events and LP events. With each of those seismic "pulses", an increment in the number and area of fumarolic degassing was observed, while dry tilts were recording radial inflation (Barboza et al., 2003b). These events were interpreted as the effect of hydro-fracturation phenomena at depth (Barboza et al., 2003b) promoted by an increase in pressure, possibly due to overheating of the hydrothermal system by the deeper magmatic source (Tassi et al., 2004).

The recorded waveforms often had emergent onset and a spindleshape envelope; the identification of $\mathrm{P}$ and $\mathrm{S}$ arrivals is extremely challenging, causing problems for locating the events with traditional techniques and concerns about classifying them as rupture-type events. Seismograms are characterized by spindle-like amplitude increase after the $\mathrm{P}$ wave and most of the energy shifted to the late part of the seismograms. These types of signals were explained by a diffusion model (i.e. at Merapi Volcano in Indonesia) (Wegler and Luhr, 2001), according to which there are many strong heterogeneities that the direct wave can be neglected and all the energy is concentrated in multiply scattered waves. Therefore, the waveform as well as the polarization properties at Turrialba data could be explained by multiple scattering in the highly heterogeneous structure of the volcano, this indicating that those events may be interpreted as VT-type events.

This second phase (2001-2006) was marked by a progressive increase of the fumarolic output rate accompanying the seismic activity. An increasing magmatic contribution is evidenced by the sharp increase in the concentrations of $\mathrm{SO}_{2}, \mathrm{HCl}$ and $\mathrm{HF}$ (Tassi et al., 2004; Vaselli et al., 2010), likely due the fact the hydrothermal aquifer was not able to efficiently buffer the uprising magmatic fluids. Despite the strong compositional changes recorded in this stage, no significant variations of the outlet fumarolic temperatures were measured. This would indicate that the discharging fluids were still controlled by the presence of a shallow aquifer heated by the magmatic fluids, capable to open new pathways as the deep system was overpressuring. No variations of the helium and carbon isotopes were detected, being clustering around the values measured in the first stage (Shaw et al., 2003; Tassi et al., 2004; Vaselli et al., 2010).

The third phase started in 2007, when two important seismic swarms (see Section 5.1), accompanied and followed by a dramatic increase of the fumarolic discharge rate even in areas distant from the crater summit (i.e., Ariete Fault), occurred. Gas and condensate analyses showed that the contribution from the magmatic system to the crater fumaroles largely exceeded that of the hydrothermal fluids (Vaselli et al., 2010).

Therefore, we can conclude that the two seismic swarms marked the moment the system "opened": the amount of degassing substantially increased and the balance between a magmatic and hydrothermal system changed, the former becoming dominant. We can speculate on the events that may have triggered the third phase, as follows:

i) Response to a critical level of overpressure at depth, which led to system failure and the opening of new pathways for uprising fluids, causing all the described changes in gas geochemistry and seismicity. The meteoric-fed aquifer at shallow depth was at least locally superheated by an increasing amount of hot fluids ascending from the deep-seated reservoir. The geochemical data of gas samples collected in 2008 indicate a still on-going magmatic-dominated regime, confirming the trend initiated in 2007. The low quality of seismic data does not allow inferring a precise location of the events and a possible migration of the hypocenter towards shallower depths, which could be good evidence of a rising dyke. However, the fumarolic gas composition in this phase shows a significant increase of HF. This can be related 


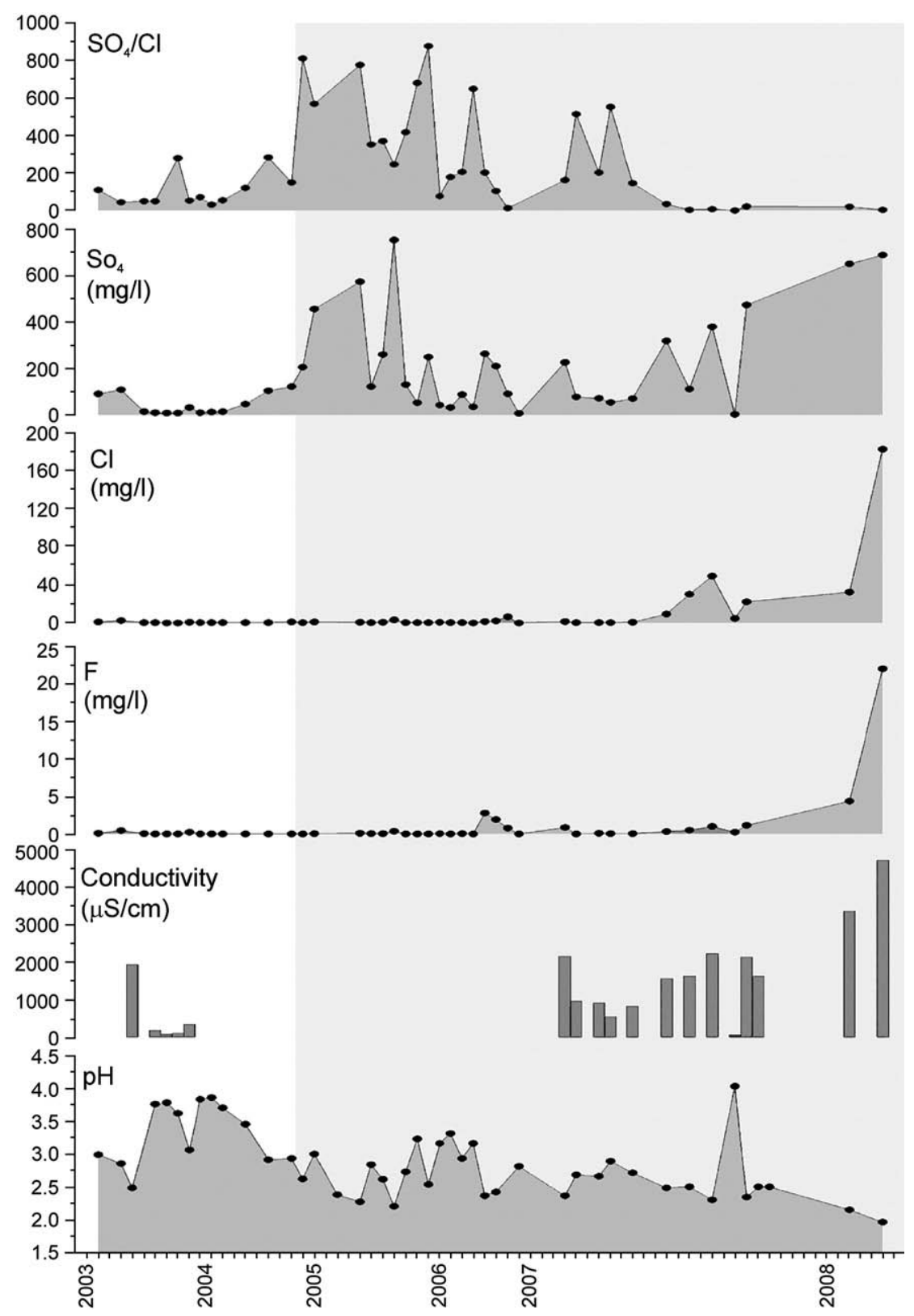

Fig. 15. From top to bottom, $\mathrm{SO}_{4} / \mathrm{Cl}, \mathrm{SO}_{4}, \mathrm{Cl}, \mathrm{F}$, electrical conductivity and $\mathrm{pH}$ for rainwater samples collected at the West crater rim between 2003 and early 2008 .

to fact that when fresh (volatile-rich) magmas are degassing high $\mathrm{SO}_{2} / \mathrm{HF}$ ratios are observed, whereas low $\mathrm{SO}_{2} / \mathrm{HF}$ ratios are more characteristic of late stages of volcanic degassing (e.g. Aiuppa, 2009 and references therein). This would support the hypothesis that the occurrence of a new magma batch at depth can tentatively be ruled out, although the behaviour of fluorine in magmatic and hydrothermal systems is not very well assessed.

ii) Response to seismicity related to tectonic stress. The seismicity recorded since the '90s in the area mapped well the major tectonic faults in the area (G. Soto, Pers. Comm.), showing also a migration in time from SW to the NE direction along those faults. Epicentre distribution of the 2007 seismicity map along the major tectonic fault crossing the volcano area, and seems to fit well the general SW-to-NE migration pattern. Tectonic movement could have affected the volcano system, inferring a possible tectonic origin for the 2007 seismicity.

The post-2007 seismicity fits well the model of an open system that favoured magmatic degassing. As previously described, this seismicity consisted of impulsive, often high amplitude, deep events, recurrently followed by episodes of harmonic tremor, lasting for several minutes up to several hours. The fundamental frequency $f_{1}$ of the harmonic tremor sequences was the same at all recording stations, indicating that it was a source and not a path or site effect. The frequencies of the overtones (normally 3 or 4 ) are observed to be slightly shifted with respect to $n \times f_{1}$. This could be suggesting a resonance effect in a conduit: when resonance occurs in bodies such as organ pipes, and overtones are excited, there are seldom more than two or three harmonics present. In addition, the theoretically calculated higher resonance frequencies are rarely matched precisely by measurements. In reality, the geometry of a resonator, as sampled by the overtones (the shorter wavelengths or higher frequencies), is not the same as that sampled by the fundamental. As a result, the frequencies of the overtone resonances are shifted slightly with respect to $\mathrm{n} \times \mathrm{f}_{1}$ (Hellweg, 1999).

In summary, we were observing deep impulsive 'start-off' events, related to high pressure degassing events occurring at depth, that put the conduit into resonance. 

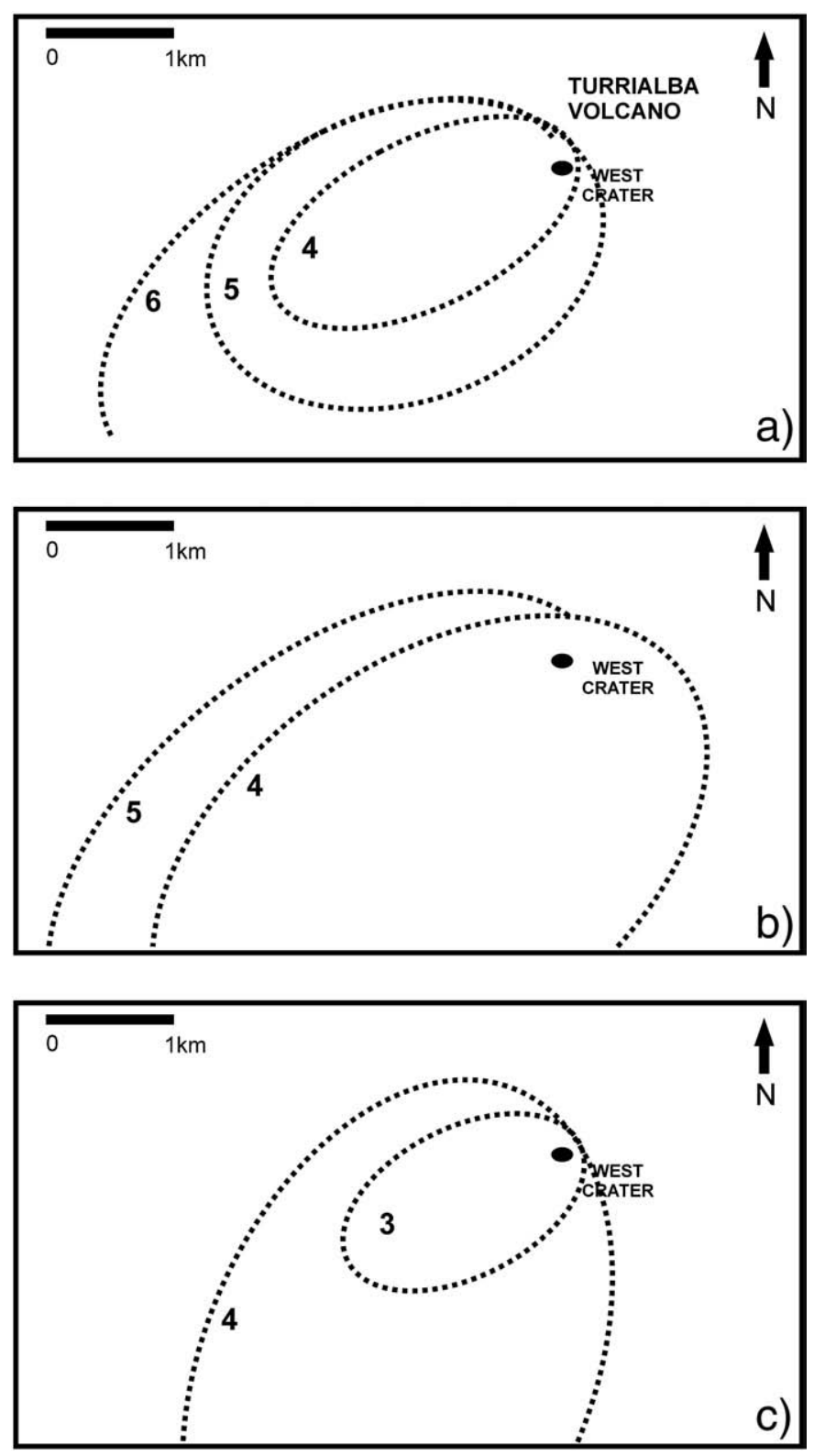

Fig. 16. Exemplified sketch to illustrate the extension of the area affected by acid rain towards the SW flank of the volcano; the isolines of $\mathrm{pH}$ (dotted lines) for a) August 2008, b) November 2007, and c) February 2008, were freely drawn following Soto et al. (2008). Monthly reports are publicly available from http://www.rsn.geologia.ucr.ac.cr/ Vulcanologia/volcanturrialba.html.

Similar sequences were observed at other volcanoes, as for example Arenal (Costa Rica), where the sequence of explosions, whoosh and chugs, followed by harmonic tremor carried a striking resemblance to the sequences observed at Turrialba (Fig. 3 in Benoit and McNutt, 1997). While at Arenal volcano, visible and/or audible explosions correlate with those recorded sequences, none of the signals recorded at Turrialba has been correlated with anomalous audible or observable events: this would support the conclusion that these degassing events are deep (as deducted by polarization analysis). The gliding effect is also present in the Arenal data (Benoit and McNutt, 1997) and it is interpreted as a variation of pressure and gas content in the conduit: the low frequencies following the whoosh correspond to when the conduit was enriched in gas (slowest velocities), the shift forward to higher frequency correspond to when the gas was lost and the acoustic velocity increased (Benoit and McNutt, 1997). In the case of Turrialba, this interpretation could be validated with an observed correlation between the occurrence of those seismic events and gas emissions observed by the DOAS stations, once the calibration of the instruments will be finalised.

Gas was definitely present in the conduit when these sequences were recorded: Auto-Regressive Time analysis (Lesage et al., 2002; Lesage, 2009) on moving windows was performed to extract frequency and quality factor versus time on the tremor fundamental frequency, at the crater station. Results yield to $Q$ values in the range $1-60$, indicating a very high level of gas concentrations (Kumagai and Chouet, 1999). Lowering of $Q$ values over time (months) was observed during the first semester in 2008, and this could be interpreted as the effect of increasing gas percentage in the mixture filling the conduit, although no enough constraints on the source locations were available to discharge a frequency-location effect.

The compositional evolution of the fumaroles is obviously related to changes in the equilibrium between a hot deep magmatic source and a cold shallow aquifer that operates as a buffer (Tassi et al., 2004), with strong inputs of $\mathrm{SO}_{2}$-rich fluids from the magmatic system affecting the hydrothermal reservoir. During periods of relatively low fumarolic emission (a purely "hydrothermal" stage), the boiling of the hydrothermal aquifer, heated by uprising magmatic fluids, progressively caused overpressure at depth, until the opening of new pathways for uprising fluids occurred ("hydrothermal-magmatic" and "magmatic-dominated" stages). In this respect, the variations of $\mathrm{Rn}$ concentrations versus time were decoupled with respect to the three stages as defined by the seismic and gas geochemical records. The period 1999-2002 (which corresponds in time at the occurrence of repeated seismic pulses) was indeed marked by a general increase in Rn concentrations at La Silvia and La Fuente stations. Their values sharply decreased afterwards. This could be related to the fact that the advective circulation was not sustained after 2002, partly explaining the fact that no significant variations were recorded.

\section{Conclusions}

The evolution of fumarolic composition and seismic activity occurred since 2000 at the Turrialba volcano can be related to changes in the equilibrium between a hot deep magmatic source and a shallow aquifer, the latter operating as a buffer (Tassi et al., 2004), with strong inputs of $\mathrm{SO}_{2}$-rich fluids from the magmatic system affecting the hydrothermal reservoir. During periods of relatively low fumarolic emission ("hydrothermal" stage, corresponding to the first few years of observation), the boiling of the hydrothermal aquifer, heated by uprising magmatic fluids, progressively caused overpressure at depth, until the opening of new pathways for uprising fluids occurred, moving to a "hydrothermal-magmatic" and eventually a "magmatic-dominated" stage. These phases well correspond to the seismic pulses recorded, for example, in 2001, 2005 and 2007. After the occurrence in mid 2007 of two important seismic swarms of events interpreted as volcano-tectonic, the seismicity was mainly dominated by tremors related to degassing events. Very important changes were observed in temperature, gas and condensate geochemistry at the fumarolic discharges from both summit area and the S-SW flanks of the volcano. Data from early 2008 showed a further increase of the most soluble magmatic compounds, suggesting the degassing of an already volatile-depleted magma. Accordingly, no new fresh magma batches replenished the magmatic chamber. Deformation data indicate a plausible inflation pattern in 2007 reversed into deflation in early 2008 (but characterization and quantification of the deformation is not possible due to the strong limitations of the networks).

The data relative to the geochemistry of the fumarolic discharges (the only data which were already published in this work) had identified the same three phases. The results obtained integrating the seismicity, deformation and remaining geochemistry data available have identified the three stages of activity in the period of observation, deriving by the delicate equilibrium between the 
hydrothermal and magmatic reservoirs. Those results confirm the findings from the previous published works, based mainly on the geochemistry of the fumarolic discharges.

The available seismic and geodetical data at Turrialba pose limitations in the interpretation of what might have triggered the onset of the unrest at Turrialba. An accurate definition of the location and the possible migration at depth of the hypocenters with time as well as the precise calculation and localization of the ground deformation (which would have helped to univocally infer whether there was a magmatic intrusion that could have caused this unrest) could not be obtained. Epicentre distribution in the 2007 seismicity mapped along the major tectonic fault in the area, and seemed to fit into a general SW-NE migration of the seismicity since the 1990s. This would infer a possible tectonic origin for the 2007 seismicity: tectonic movement could have affected the volcano system, causing pressurisation and mobilization of fluids and the opening of the system or the breakage of a sealing surface with the consequent release of fluids.

Whatever the origin of the unrest, there is no doubt that Turrialba represents a serious threat for the population and the economical activity of Costa Rica. As a consequence, more efforts should be done to minimize the volcanic hazard through a more efficient and up-todated monitoring (geophysical, ground deformation and geochemical) activity coupled with realization of a map of volcanic risk and a related evacuation plan for those people potentially exposed to the volcanic activity. These minimal requirements are presently missing. This gap should necessarily be filled particularly if we consider that while completing the present paper four small (phreatic) explosions occurred on 4th January 2010, at the West crater.

\section{Acknowledgements}

The authors would like to thank M. Protti for the tiltmeter data, M. Palo for polarization analysis programme, G. Soto and J. Ibanez for discussions, as well as two anonymous reviewers for their suggestions on the manuscript.

\section{References}

Aiuppa, A., 2009. Degassing of halogens from basaltic volcanism: insights from volcanic gas observations. Chemical Geology 263, 99-109.

Alvarado-Induni, G.E., 2005. Costa Rica Land of Volcanoes. EUNED, San Jose. 360 pp.

Barboza, V., et al., 2003a. Changes in the Activity of Turrialba Volcano: Seismicity, Geochemistry and Deformation. Seismological Society of America, San Juan, Puerto Rico.

Barboza, V., et al., 2003b. Changes in the Activity of Turrialba Volcano: Seismicity, Geochemistry and Deformation. 8th IAVCEI Gas Workshop, Nicaragua and Costa Rica.

Benjamin, E.R. et al., 2007. High water contents in basaltic magmas from Irazu Volcano, Costa Rica. Journal of Volcanology and Geothermal Research, 168, 68-92.

Benoit, J.P., McNutt, S.R., 1997. New constraints on source processes of volcanic tremo at Arenal volcano, Costa Rica, using broadband seismic data. Geophysical Research Letters 24 (4), 449-452.

Carr, M.J., Feigenson, M.D., Bennett, E.A., 1990. Incompatible element and isotopic evidence for the tectonic control of source mixing and melt extraction along the Central American arc. Contributions to Mineralogy and Petrology 105, 369-380.

Cheminée, J.M., Javoy, M., Delorme, H., 1982. Temperature and Gas Data from Turrialba.

Chen, W., Hill, C., 2005. Evaluation Procedure for Coordinate Transformation. Journal of Surveying Engineering, 131 (2), 43-49.

Chiodini, G., Cioni, G.R., Guidi, M., Raco, B., Marini, L., 1998. Soil $\mathrm{CO}_{2}$ flux measurements in volcanic and geothermal areas. Applied Geochemistry 13, 543-552.

Fernández, E., 1987. Caracterización química de la precipitación ácida en el área adyacente al Volcán Turrialba. Universidad Nacional, Heredia Costa Rica.

Galle, B., 2002. Preliminary report from studies of volcanic $\mathrm{SO}_{2}$ emission in Nicaragua and Costa Rica, March 2002, using DOAS spectroscopy., Department of Radio and Space Science, Chalmers University of Technology, S-412 96 Gothenburg, Sweden

Galle, B., Oppenheimer, C., Geyer, A., McGonigle, A., Edmonds, M., Horrocks, L.A., 2003. miniaturised UV spectrometer for remote sensing of $\mathrm{SO}_{2}$ fluxes: a new tool for volcano surveillance. Journal of Volcanology and Geothermal Research 119, 241-254.

Gerlach, T.M., Nordlie, B.E., 1975. The C-O-H-S gaseous system, part II: temperature, atomic composition and molecular equilibria in volcanic gases. American Journal of Science 275, 377-395.
Giggenbach, W.F., 1987. Redox processes governing the chemistry of fumarolic gas discharges from White Island, New Zealand. Applied Geochemistry 2, 143-161.

Giggenbach, W.F., 1992. Isotopic shifts in waters from geothermal and volcanic systems along convergent plate boundaries and their origin. Earth and Planetary Science Letters $113,495-510$.

Giggenbach, W.F., 1996. Chemical composition of volcanic gases. In: T.R.I., Scarpa, R. (Eds.), Monitoring and Mitigation of Volcano Hazards. Springer Verlag, Berlin, pp. $222-256$.

Hellweg, M., 1999. Seismic signals from Lascar Volcano. Journal of South American Earth Sciences 12, 123-133.

Hilton, D.R., Fisher, T.P., Marty, B., 2002. Noble gases and volatile recycling at subduction zones. In: Porcelli, D., Ballantine, C.J., Wieler, R. (Eds.), Noble Gases in Cosmochemistry and Geochemistry. Mineral. Soc. of America, Washington, pp. 319-370

Husen, S., Quintero, R., Kissling, E., Hacker, B., 2003. Subduction-zone structure and magmatic processes beneath Costa Rica constrained by local earthquake tomography and petrological modelling. Geophysical Journal International (155), 11-32.

Kanasevich, E.R., 1981. Time Sequence Analysis in Geophysics. University of Alberta Press, Edmonton, Alberta.

Kumagai, H., Chouet, B., 1999. The complex frequencies of long-period seismic events as probes of fluid composition beneath volcanoes. Geophysical Journal International 138, F7-F12.

Lesage, P., 2009. An interactive Matlab software for the analysis of seismic volcanic signals. Computers \& Geosciences 35 (10), 2137-2144.

Lesage, P., Glangeaud, F., Mars, J., 2002. Applications of autoregressive models and time-frequency analysis to the study of volcanic tremor and long-period events. Journal of Volcanology and Geothermal Research 114, 391-417.

Linkimer-Abarca, L., 2003. Neotectonica del extremo oriental del Cinturon Deformado del Centro de Costa Rica. Universidad de Costa Rica, San Jose. 114 pp.

Mamyrin, B.A., Tolstikhin, I.N., 1984. Helium Isotopes in Nature. Elsevier, Amsterdam.

Martínez, M., 2008. Geochemical Evolution of the Acid Crater Lake of Poás Volcano (Costa Rica): Insights into Volcanic-Hydrothermal Processes. University of Utrecht the Netherlands, Utrecht.

Mogi, K., 1958. Relations between the eruptions of various volcanoes and the deformations of the ground surfaces around them. Bull. Earthquake Res. Inst. Tokyo 36, 99-134.

Muller, C., van der Laat, R., Cattin, P.H., del Potro, R., 2009. Three-dimensional stochastic adjustment of volcano geodetic network in Arenal volcano, Costa Rica. Geophysical Research Abstracts 11 (EGU2009-1012-3).

OVSICORI-UNA, 2007. Report of the Turrialba Volcanic Activity. Smithsonian Institution.

OVSICORI-UNA, 2008. Report of the Turrialba Volcanic Activity. Smithsonian Institution.

Platt, U., 1994. Differential optical absorption spectroscopy (DOAS). In: Sigrist, M.W. (Ed.), Air Monitoring by Spectroscopic Techniques. Chemical Analysis Series. Wiley, New York, pp. 27-84.

Poreda, R.J., Craig, H., 1989. Helium isotope ratios in circum-Pacific volcanic arcs. Nature $338,473-478$.

Protti, M., McNally, K., Pacheco, J., González, V., Montero, C., Segura, J., Brenes, J. Barboza, V., Malavassi, E., Güendel, F., Simila, G., Rojas, D., Velasco, A., Mata, A., Schillinger, W., 1995. The March 25, 1990 ( $M w=7.0, M L=6.8)$, earthquake at the entrance of the Nicoya Gulf, Costa Rica: its prior activity, foreshocks, aftershocks, and triggered seismicity. Journal of Geophysical Research 100 (B10), 20345-20358.

Protti, M., Guendel, F., Malavassi, E., 2001. Evaluación del Potencial Sísmico de la Península de Nicoya. Editorial Fundacion UNA, Heredia, Costa Rica. 144 pp.

Reagan, M., Duarte, E., Soto, G.J., Fernandez, E., 2006. The eruptive history of Turrialba volcano, Costa Rica, and potential hazards from future eruptions. In: Rose, W.I., et al. (Ed.), Volcanic hazards in Central America: Geological Society of America Special Paper, pp. 235-257.

Seidel, J.L., 1982. Radon emanometre, PhD Thesis, Universite de Clermont Ferrand Il, France.

Shaw, A.M., Hilton, D.R., Fischer, T.P., Walker, J.A., Alvarado, G.E., 2003. Contrasting HeC relationships in Nicaragua and Costa Rica: insights into C cycling through subduction zones. Earth and Planetary Science Letters 214, 499-513.

Soto, G., 1988. Estructuras volcano-tectonicas del volcan Turrialba, Costa Rica, America Central, Actas Quinto Congreso Geologico Chileno, Santiago, pp. 163-175.

Soto, G., Hernandez, J.F., Rojas, M., Panagua, C., 2008. Lluvia acida en el volcan Turrialba. Costa Rica: abril 2007-abril 2008, IX Congreso Geologico de America Central, San Jose, Costa Rica, pp. 183-184.

Taran, Y.A., Pokrovsky, B.G., Esikov, A.D., 1989. Deuterium and oxygen-18 in fumarolic steam and amphiboles from some Kamchatka volcanoes: "andesitic waters". Doklady Akademii Nauk SSSR (304), 440-443.

Tassi, F., Vaselli, O., Barboza, V., Fernandez, E., Duarte, E., 2004. Fluid geochemistry and seismic activity in the period 1998-2002 at Turrialba volcano (Costa Rica). Annals of Geophysics 47 (4), 1501-1511.

Vaselli, O., Tassi, F. Duarte, E. Fernandez, E. Poreda, R., Delgado Huertas, A. 2010. Evolution of fluid geochemistry at the Turrialba volcano (Costa Rica) from 1998 to 2008. Bullettin of Vulcanology 72 (4), 397-410.

Wegler, U., Luhr, B.-G., 2001. Scattering behaviour at Merapi volcano (java) revealed from an active seismic experiment. Geophysical Journal International 2001 (145) 579-592.

Yokoyama, I., 1971. A model for the crustal deformations around volcanoes. J. Phys. Earth 19, 199-207. 